\title{
病原大腸菌 $(\mathrm{O} 28 \mathrm{ac}: \mathrm{K} 73)$ 亿よる集団食中毒（昭和43年7月）
}

\section{1. 事件の発端}

昭和43年 7 月 7 日三重県桑名市城南小学校で食中毒が 発生したが，当日は日曜日であったため翌月曜日学校に 登校する児童が非常に少なかった，そこで学校から久席 児童宅に電話その他で連絡の結果，食中毒の疑いのある ことが判明, 学校から所轄の保健所に連絡, ただちに調 查を開始した。

\section{2. 発生の日時}

昭和 43 年 7 月 5 日 7 月 9 日

3. 発生の経緯

7 月 6 日は土曜日， 7 日は日曜日であることから学校 給食は行なわれず，しかも患者の大半は7 日の日曜日に 発生していることから一応 5 日金曜日の給食が疑われ た。 そこで曝露時点推定のため 5 日以降 9 日までの患者 の経時的発生数を調査したところ 1 図に示すとおりであ った，いまこれを共通経路，単一懪露感染と仮定し曝露 時点を推定すると，公式 $=2.14$ となり，7月 5 日 13 15 時の間に污染が起こったことになり，5 日の給食が疑わ れた。

4. 規模
桑名市城南小学校は児童数 484 名, 教職員 22 名の計 506 名である. 日別患者発生数は 7 日までに87名, 8 日 37名，9 日 8 名の計 132 名で教職員も児童と同じく学校 給食を食べ若干発病したものもあったが，患者数に加え られていなかったために罹患率としては児童を対象とし て算出し，132/484=27.3\%で契食者の約1/4であった.

また患児は各学年にわたっており，性別では男女とも 同数の66名ずつであった.

5. 推定原因食

7 月 5 日の学校給食献立表は第 1 表に示寸とおりであ る. しかし5 日の給食の検食については7 日の事件発生 当日寸でに廃棄されていたので原因食が何であるかは確 定できなかった。

6. 症状

症状は第 2 表に示すとおり腹痛, 下痢, 発熱, 頭痛な どを主とする腸炎症状である.

\section{7. 病因物質}

児童の検便には SS 培地（赤琍, サルモネラ）および TCBS（腸炎ビブリオ）をそれぞれ用いて検索を行なっ たが，いずれも陰性におわった，そこで病原大腸菌を疑

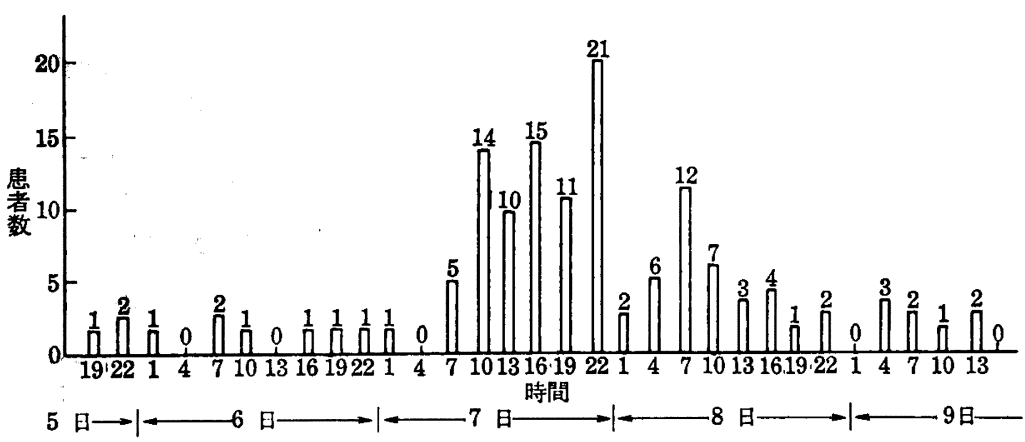

第 1 図患者の経時的発生数

第 1 表 7 月 5 日給食献立表

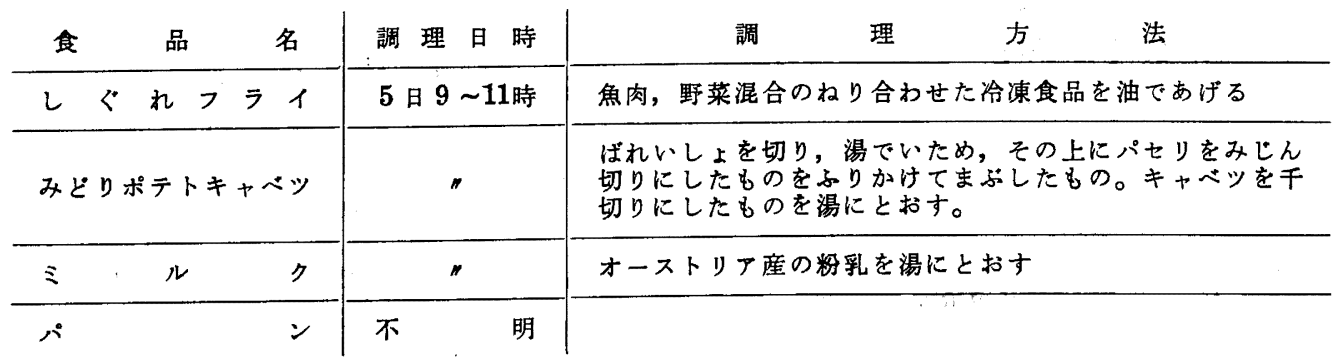




\begin{tabular}{|c|c|c|c|c|c|c|c|c|}
\hline 症状 & 腹痛 & 下溂 & \begin{tabular}{|l} 
発熱 \\
$\left(8^{\circ}\right)$ \\
\end{tabular} & 嘔気 & 嘔吐 & 頭痛 & 䢽急 & 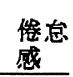 \\
\hline 実数 & 75 & 78 & 78 & 29 & 28 & 75 & 9 & 3 \\
\hline$\%$ & 56.8 & 59.1 & 59.1 & 22.0 & 21.2 & 56.8 & 6.8 & 2.3 \\
\hline
\end{tabular}

い, SS 培地に認められた赤色集落につき病原大腸菌 の抗血清 (東芝化学) でスライト㠜集を行なったところ OK 血清 3 群に凝集するものがあったので，さらに詳細 に検討したところ 028acK73 であることがわかった。 検出率は児童 484 名中73名で15.1\%であった。

ウィダール反応: 患者10名の急性期と回復期 (間隔 2 週間）の血清を採取し，分離菌との間にウィダール反応
を行なったところ，急性期にはいずれも50倍で陰性であ ったが，回復期には200 800倍に上昇していた。

薬剂耐性試験: 分離菌の薬剤耐性試験を行なったとこ

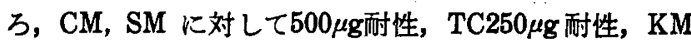
$10 \mu \mathrm{g}$ 耐性, パンフラン $\mathrm{S} 1 \mu \mathrm{g}$ で感性であった. この点 三重県下で分離されている赤浰菌とほぼ同様の耐性バタ ーンである.

\section{8. 処置}

事件解決までに数日を要したために，学校が夏休みに なるまでに数日を残すのみであったため，9月の二学期 開始まで給食を中止，その間給食場の大掃除，従業員に 対する衛生教育などを所轄の保健所の指導により実施し た。
(国立衛生試験所 鈴木 昭)

\section{折詰べん当による食中毒(昭和43年 9 月)}

\section{1. 事件の発端}

昭和43年 9 月 6 日午後 6 時から, 航空自衛隊基地で家 族同伴の慰安盆踊大会が催された。，食にまんじゅう 1,409個と折詰べん当 1,504 個が参会者に配られたが，そ の日の夜半から11日にかけて, 自衛隊員扰よびその家族 の間に，多数の食中䓯患者が発生した。9 日早朝に自衛 隊から保健所にその旨の届け出があった。

\section{2. 事件の経緯}

ます原因食としては，まんじゅ5だけを食べた舞踊団 員45名からは1名の中毒患者も出ていないので, 折詰べ ん当に疑いがもたれた。

折詰べん当は宮崎市内の某食堂が調製したもので，原 材料を 5 日に仕入れ， 6 日の早期 4 時から豚肉, 魚, 䊿 肉の調理をはじめた. 正午頃から詰合せをして15時に完 了し，16時に自衛隊に納入した，自衛隊では17時から隊 員や家族達に分配して，およそ18 22時の間に摄食して いる. したがって，調理のはじめから摂取するまでに， 約14 18時間を経過している. 患者数は 6 日夜半から11 日までに合計 346 名（発病率23\%）に達した。

3. 症状

（1）潜伏期一摄食後 $2 \sim 134$ 時間の間に発病して いる. 患者の約半数は $36 \sim 65$ 時間で平均 48 時間であっ た.

（2）症状一一第 1 表の上5に, 頭痡・発熱と腹痛・ 下浰が主要症状で, 潜伏期と共に定型的なサルモネラ中 帮の所見を示した。

体温は，95名について正確に測られたが，平熱が49.5 \% と約半数を占めた. $37 \sim 38^{\circ}$ が $32.6 \%, 38 \sim 39^{\circ}$ が 14.7 $\%, 39^{\circ}$ 以上は $3.2 \%$ で, 全般的に発熱は軽度であった。
下利は，标様性が主で，一部に粘液を混じた者もあっ たが, 血液を混じた者はなかった. 回数は，3４回が $33.8 \%$ で最も多いが, $11 \sim 14$ 回も11.1\%を数え, 平均 5 回であった.

経過は，患者の 3 割は $2 \sim 3$ 日で回復したが，回復ま でに10日前後を要した者もあった，死亡者はなかった。

4. 病因物質

（1）患者一一事件発生後届け出があるまですでに2 日半を経過していたが55名について検便をした，そのう ちの30名はクロロマイセチンなどが投与されていた。し かし, 赤蜊の場合と異なって，第 2 表に示すよ5に菌検

\begin{tabular}{|c|c|c|c|c|c|}
\hline \multirow[b]{2}{*}{ 症 } & \multicolumn{3}{|c|}{ 第 1 表＼cjkstart症 } & 状 & \multirow[b]{2}{*}{$\%$} \\
\hline & & 状 & 患 & 者 数 & \\
\hline 下 & 㾰。 & 水 様 & & 241 & 69.2 \\
\hline & & 粘 液 & & 74 & 21.2 \\
\hline 腹 & 痛 & 下 部 & & 186 & 53.8 \\
\hline 頭 & 痛 & & & 148 & 40.0 \\
\hline 恵 & 感 & & & 99 & 28.6 \\
\hline 発 & 熱 & & & 192 & 55.5 \\
\hline 嘔 & 吐 & & & 24 & 6.9 \\
\hline
\end{tabular}

第 2 表 食中毒患者の菌検索成綂

\begin{tabular}{|c|c|c|c|c|c|}
\hline \multirow[b]{2}{*}{ 投 薬 } & \multirow[b]{2}{*}{ 被棆 者数 } & \multicolumn{2}{|c|}{ 菌 } & 性 & 者 \\
\hline & & S.block. & S. pots & $\begin{array}{c}\text { S. block. } \\
+ \\
\text { S. pots. }\end{array}$ & 計 $(\%)$ \\
\hline 投葉前 & 25 & 8 & 2 & 4 & $14(56.0)$ \\
\hline 投薬中 & 30 & 17 & 2 & 3 & $22(73.3)$ \\
\hline
\end{tabular}


第3 表 食品からの菌検出方法と成㘘

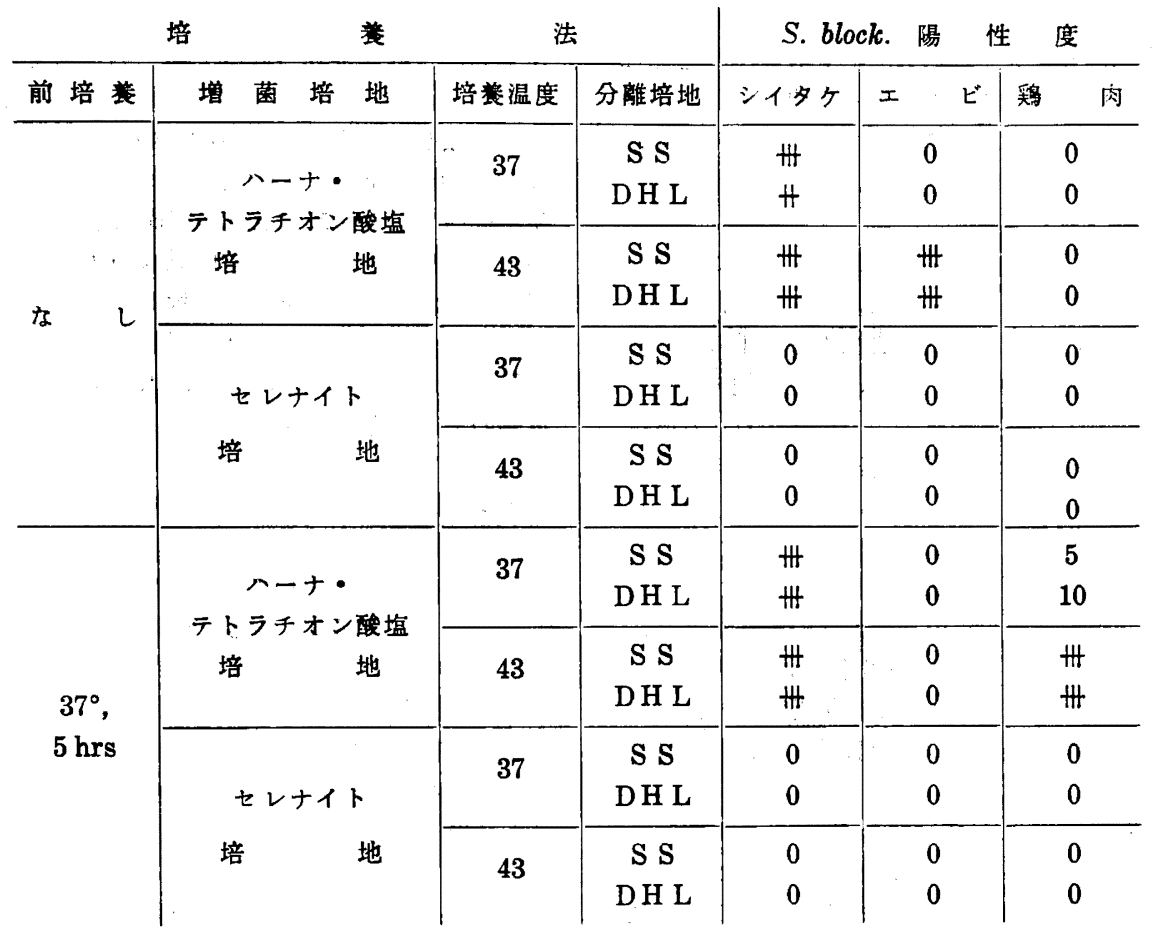

注＊はコロニー数を示す

出率は未投与者で $56 \%$, 投与中の者で $73.3 \%$ と,抗生物質 の投与は菌検索に影響はなかった，検出菌は 2 種類で，

S. blockley が25名から，S. potsdamが 4 名からまた 7 名からは両菌種がそれぞれ検出され合計36名（陽性率 65\%）からサルモネラ菌が検出された。

（2）食品一一保健所で検査後保管していた折詰べん 当を入手し，内容を食品別に検査した．直接分離培湌で は寸べて陰性であったが, 第 3 表のように增菌培莨を併 用することによって，シイタケエビおよび鷄肉から
S. blockley が検出された. S. potsdam は検出できなか った。このような場合, 選択增菌培地で增菌する一方, 普通ブイヨンで $37^{\circ}, 5$ 時間, 前培養した後汇選択增菌 する方法を併用すると，検出率が高くなるよらに思われ た。增菌培地は，セレナイト培地は不適で，ハーナ・ テトラチオン酸塩培地が 良好であった。 また培養温度 は，37゚より $43^{\circ}$ の方がよかった。

(宮崎県衛生研究所 福田武夫)

\section{米邓 油中毒 (昭和43年10月)}

\section{1. 事件の発端}

昭和43年10月 4 日大牟田市の一市民から保健所に食中 走によると思われる奇病の届け出があり原因食品は食用 油と推定されるとの申し出があった。

2. 発生の経緯および処置

この届け出はただちに福岡県さらに厚生省に通知され 原因食之思われる食用油の一部が厚生省を通じて国立衛 生試匼所に送付されると同時に現地での本格的な調査が
開始されたすなわち九州大学附属病院に同様の症状を 呈する患者が北九州市からも来院していること,これら 患者はカネミ合庫会社製缶入り米奻油を小分けして使 用していたこと等が判明し，また保健所を主体として実 施した度学調査からもカネミ合庫会社製米奻油が少な くとも患者の共通食品であることが明らかにされた。こ こに米油による食中毒の可能性がきわめて濃厚とな $\eta$, 北九州市は 10 月15日カネミ倉庫会社に対し営業停止 
を命ずるに至った。

この処置に前後して福岡県に行政担当者を中心とした 県油症対策本部, 九州大学に同大学研究者を中心とした 油症研究班, な厚生省に米奻油中毒事件対策本部等 が設置され緊密な連熬のもとに原因究明，患者の発見， 治療法の確立等の推進がはかられた。

3. 症状

患者の一般的症状は九州大学附属病院での診察結果を 総合し，つぎの通りであることが明らかにされた。すな わち上眼瞼の浮腫, 眼脂の增加, 食欲不辰, 爪の変色変 形, 脱毛, 両肢の浮腫, 嘔気, 湢吐, 四肢の脱力感, 乙 びれ感，関節痛および症瘡様皮疹等の症状が見られとく に眼脂の增加, 爪の变色扣よび痤瘕様皮疹は本症を疑わ せる要因とされた。

\section{4. 原因物質}

中毒原因物質としてはまず10月14日久留米大学より患 者宅の使用残油からヒ素が検出されたとの報告があり， 続いて同様の報告が他の $2 \sim 3$ の機関からも発表された が，この説は九州大学での再検討の結果否定され，国立 衛生試験所の成績でも七素その他の有害性金属類の含有 はすべて否定された。

一方油そのものの品質, すなわち 酸価, カルボニル 価, 過酸化物価, 構成脂肪酸あるいはビタミン D含有 量, さらに米ぬか油の抽出, 精製工程では使用された食 品添加物類についても詳細に検討されたが中毒に結びつ くような異常は全く認められなかった。

他方, 国立衛生試験所のけい光X線分光分析および電 子捕獲型検出器によるガスクロマトグラフィーの両成績 から中毒原因物質として有機塩素化合物の可能性が濃厚 となった。このようなとき油症研究班は米奻油製造工 程のらち脱臭処理の加熱媒体として塩化ビフェニル (PCB) が使用されていることを探知し，カネミ倉庫会 社でも PCB 製剤であるカネクロールを使用しているこ とが確認され，油症研究班および国立衛生試験所におい、 て中毒原因食用油中の異常物質がカネクロール由来化合 物であることを確認するに至った。

5. その他の参考事項
なお度学的調查も強化され患者の診断基準の設置, 力 ネミ製米奻油摂取の有無と発症との関係, 該食用油の 流通範用と販売経路等に関し精力的な調查検討が加えら れた結果, この食用油が中毒原因食品であることがより 明確となり, さらに該食用油中の異常物質がカネクロー ル由来物質であることが明らかにされた。 ついで国立衛 生試験所で動物実駼による PCB および患者宅使用残油 の毒性が検討された。一般所見は当然のことながら油症 患者の臨床所見と完全には一致しなかったものの, 両試 料によりニワトリでは各種類似症状が見られ，マウスで む爪の変化が確認され，ここに本中毒の病因物質が毒性 試験の上からも食用油中のカネクロール由来物質である ことが明らかにされた。

污染の原因についてはその後九州大学によるカネミ倉 庫会社工場施設の諸検査から脱臭缶内加熱のための熱媒 体用ステンレス製バイブに微細な穴のあることが発見さ れ, ここから熱媒体である PCB が漏れて米始か油に混 入したものと推定されるに至った。 カネミ製米ぬか油の ロット別恰査から PCB で污染されたものは43年 2 月の 限られた期間の製品のみであることが明らかにされ污染 のおそれのない製品については後に販売が許可されたが パイブの微細な穴から限られた期間にのみが漏れた理由 は明らかでない。

本中毒の届け出者数は 14,000 名を越之一時は化学的物 質による食中書事件としてはその規模に打いて昭和 30 年 のヒ素入りドライミルク中毒事件に匹敵するものと考元 られたが精密梌疹その他の調查の結果中毒患者（油症患 者）は約 1,000 名であることが明らかとなった。これら の患者の治療開発のため厚生省および九州大学をはじめ とする多くの研究者が研究に努めて来たが今に至るも有 効な薬剤を発見するに至っていない。

な怙本中毒事件発生の約半年前に西日本一帯で数十万 羽のニワトリが死亡する事件があったが米油中事 件に関して調査の結果飼料に混ぜられた 当時のカネミ 製ダーク油からも PCB 由来物質が検出され本ダーク油 が中毒原因食用油製造時の副産物であったことも判明し た. (国立衛生試験所田辺弘也)

\section{野生はち蜜 中毒(昭和44年 2 月)}

\section{1. 事件の概要}

昭和44年 2 月 3 日午後 4 時頃, 秋田県秋田郡鷹巣町七 日市字明利又大湯津内の山林に扎いて, 附近の部落の農 民が新切り作業のために立木を伐採中に, 直径 $30 \mathrm{~cm} く ゙$ らいの山ぶな (Fagus crenata Blume) の穴（地上約
$2 \mathrm{~m})$ に巣を作っているトウヨウミッバチ (Apis indica Radoszkowski)を発見し，ただちに木を切り倒し， 八チが出入りする穴を鋸で大きく切り開き，その中に貯 蔵されている筌を巣とともに手つかかみで取り出し，その 場で生のま摂食し，巣は吐き出した。そその祭に摄食 
第 1 表 野生活ち蜜播食者（8名）の症状

\begin{tabular}{|c|c|c|c|c|c|c|c|c|c|c|c|c|}
\hline 類 & 嘔 & 吐嘔 & 気悪感戦搮| & 卧 & 頭 & 痛脱力 感湖 & 痛 & 氛意䤘障害 & 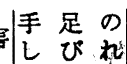 & 隐忘感 & 妙まいい & 発 汗 \\
\hline 患 者 数 & 6 & 7 & 1 & 8 & 2 & 3 & 3 & 2 & 3 & 2 & 5 & 1 \\
\hline 発現率 (\%) & 75 & 87.5 & 12.5 & 100 & 25 & 37.5 & 37.5 & 25 & 37.5 & 25 & 62.5 & 12.5 \\
\hline
\end{tabular}

者男子 8 名（30代 5 名，40代 2 名，50代 1 名）全員が口 中に灼熱感と苦味を覚えたという．撕食後 1 時間ぐらい で第 1 表に示すような症状が認められ，発病率は $100 \%$ であり，5ち 6 人は入院加療を行なった，患者中 2 名に 意識障害のあったのが本事件の特改である.

\section{2. 中毒原因物質の検索}

検体はち䖝をスライドグラス上に無水フルコールで固 定し,これをゲンチフナパイオレットで染色し，鏡検した ところ検体はち蜜中には多数の花粉粒が認められた ${ }^{11}$.

最も多くみられた花粉粒はヤマトリカブト（Aconitum japonicum Thunb. var. montanum Nakai) の花粉粒 のデータとよく一致した. トリカブト属 (Aconitum) は日本各地に自生し，観賞用としても栽培される植物で あって，キッネノボタン科 (Ranunclaceae) の多年生 草本である。茎は細長く直立して高さは $1 \mathrm{~m}$ 内外に達 し，葉に深い切れ込みがあって深緑色をしている．秋に 紫色の花を開き，その上方のガク片の形がかぶとに似て いるのでこの名がある. 検体はち蜜中の花粉は，あるい は秋田県下に多く分布するオクトリカブト（Aconitum japonicum Thunb.) のものかとも推定されるが，断定 はできない.トリカブトには猛毒性のアルカロイドのア コニチン $\left(\mathrm{C}_{84} \mathrm{H}_{47} \mathrm{NO}_{11}\right)$ を含むために，誤用その他の 誤によって，これまでにもしばしば中弯を起こした例が ある. 昔から本植物のエキスは書短を作るのに用いら れ，アイヌ族は能狩りにこれを使らといわれ，根を干し たものは鳥頭（うず），附子(ぶし）などの名がつけられ ている. したがって当該はち袓中のフコニチンおよび関 連物質の（メサアコニチンおよびヒポフコニチンなど） の存在を確認することが必要であると考え, 以下の処置 を取った。

a アコニチンの顕微鏡による検鏡試験 ${ }^{2}$ ：はち蜜試 料 $5 \mathrm{~g}$ を $15 \mathrm{ml}$ の水を使用して, ワーリングブレンダー で擳捧してホモジネートを調製した後, マショョ管に 移す. $5 \mathrm{ml}$ の10\% フンモニフ水を加え, $15 \mathrm{ml}$ のエー テルで $2 \sim 3$ 回抽出する. エーテル抽出物を分液漏斗に 移し水で洗う. エーテル抽出物を $2 \sim 3 \mathrm{ml}$ の $0.02 \mathrm{~N}$ 硫 酸で洗浄する.下層をメチルレッドで試験しもしアルカ リ性ならば下層は捨てる. $2 \sim 3 \mathrm{ml}$ の $0.02 \mathrm{~N}$ 硫酸で下 層がメチルレッドで酸性になるまで抽出を続ける. 微酸
性の水層についてアコニチンの試験を行な5. 小試験管 に1 2 $\mathrm{ml}$ の微酸性液をとり, $1 \sim 2$ 滴の $5 \%$ 炭酸ナト リゥム溶液を加える. 温度計でかきまぜながら $60^{\circ}$ に加 熱する. 冷却後, 液の数滴をスライドグラスに移し, 結 晶形を観察する (アコニチンは不規則な六角形を示す). 結果 : アコニチンの結晶を検出しない.

b 薄層クロマトグラフィーによるアルカロイド系 物の検出試験 : はち蜜試料 $5 \mathrm{~g}$ を $25 \mathrm{ml}$ の水を用いてワ ーリングブレンダーで擤拌してホモジネートを調製す る. ブレンダーの内壁を $10 \mathrm{ml}$ の水で洗浄する. ジネ 一トに対して BTBにアルカリ性となるまで $0.5 \mathrm{~N}$ ホモ 水酸化ナトリウム溶液を加える。 ホモジネートに $50 \mathrm{ml}$ のクロロホルムを添加して振り混ぜた後, クロロホルム 層を塩酸酸性の水で 3 回抽出し, 抽出液を合わせ, 再び $0.5 \mathrm{~N}$ 水酸化ナトリゥム溶液を添加して BTB アルカリ 性とした後クロロホルムで抽出し，濃縮して試料 $\mathrm{A}$ とす る. また附子 $5 \mathrm{~g}$ を同様の方法で抽出して試料 B とす る. 両試料についてシリカゲル Gによる薄層クロマトグ ラフィー（展開溶媒：(1)シクロヘキサン:クロロホルム: ジェチルアミン = 5:4:1, (2)クロロホルム:アセトン:シ エチルアミン $=5: 4: 1$, 発色剂 : ドラーゲンドルフ試薬) で比較する.

結果：附与と同様のアルカロイドを検出しない。

3. 給論

食中毒発生地の付近一带はトリカブトの群生地帯であ クおそらくは秋遅く分封した野生ミツバチが集めた卜 リカブトの花劉による中言であることが，花粉粒の存在 から推定された。しかしながら供試はち菠（約 $15 \mathrm{~g}$ ）か らはアコニチン等の存在を確認するには至らなかった。 なお，去る昭和38年 9 月 6 日に今回発生した所から約 4 $\mathrm{km}$ の笥巣町明利又字仙戸石の国有林でも野生はち蜜の 偰食によりこれに類似した中毒事件が起こっていること を付記する。

\section{文献}

1) 佐竹元吉：衛生武報. 87, 81 (1969).

2) Assoc. Offic. Anal. Chemists: "Official Methods of Analysis of A. O.A.C" 10th ed., 32.028 (1965).

(国立衛生試験所大阪支所 庋田雅洋) 


\title{
宮崎県で発生したボッリヌスB型菌による食中毒
}

\author{
(昭和44年 8 月)
}

\section{1. 事件の概要}

昭和44年 8 月, 宮崎県において発生したボッリヌス中 妾の概要を報告する．本中西独製キャビフに含まれ ていたボッリヌスB型菌害素が原因と推定され，キャビ アカナッペを摂食した65名中21名が発病，らち3名が死 とした.

\section{2. 事件の発端}

8 月25日17時頃，宮崎県国民年金課から宮崎保健所あ て電話があり，8月21日16時30分から国民年金事務の市 町村担当職員の会食をしたところ, 出席した課員のらち 23日（土曜）3名，25日 (月曜）2名欠勤，そのほか出 勤者 3 名が湢気, 腹痛, 咽喉頭痛, 複視等の症状を訴之 るものがあり，また欠勤者のらち入院している1名は急 性脺炎，他の 1 名は脳いっ血の後連症となっているけれ ども，食中恋われるので調查してほしい旨の連絡を らけ，翌26日朝から調査を開始した。

3. 発生期日

昭和 44 年 8 月 22日 23日

\section{4. 発生の経稦}

昭和44年 8 月21日宮崎県国民年金課が県総合庁舎で開 催した，国民年金市町村事務担当職員研修会に引続き想 親会を行ない，総合庁舎食堂調理のオードブルを掑食し た参加者および同食堂従業員からボツリヌスB型菌によ る食中弯が発生した.

5. 規 模

患者は県内一円に散在し，摄食者65名および同食堂従 業員の中から 21 名の患者が発生し，ちち 3 名が死亡し
た.

6. 原因食品および病因物質の追求

会食者が県内全域に散在していたので，摄食調査に若 干手間取ったが，マスターテーブル（第1表）からオー ドブルが原因食であり，オードブルの中ではキャビアカ ナッペ (西独製) が最も疑わしい食品と推定された.

調查開始後, 患者の症状に神経麻痷の徵候が見られる ことから,ボッリヌス中等いが濃厚となり, 細菌学 的検查もその方向で進められた。供試材料は，推定原因 食品 9 種27検体（このらち最も疑いがもたれたキャビア の空ビンはすでに搭てられており，塵埃埋却場で床掘機 まで駆使して探索したが発見出来なかったので，検査の 対象としては回収した同一社製のものを使用した）之患 者材料として, 便10名分延21検体, 吐物 3 名分 3 検体と 血清11名分延13検体であった（第 2 表）.

推定原因食品, 患者吐物および患者血清のすべてにつ いて、ボツリヌス毒素検出および菌分離を試みたが，いず れむ陰性であった．患者便10名延21検体の中から，3名 の便より B型毒素を検出した. その中の 1 名は, 原因食 摂取後16日目，他の 1 名は同じく19日目の便まで素を 検出した. また, 中○剛の 4 回目（摄食後12日）便，お よび 5 回目（摂食後13日）便よりB型菌を検出した。こ れらはいずれも浣腸便である。なお便に含まれる最高恝 素量は, 原○秀○第 2 回目便で, 320 マウス $\mathrm{LD}_{50} / \mathrm{ml}$ で あった。

7. 症 状

㴻食した翌日夕刻頃より腹部膨満感, 嘔吐, 下刹等の

第1表マスターテーブル

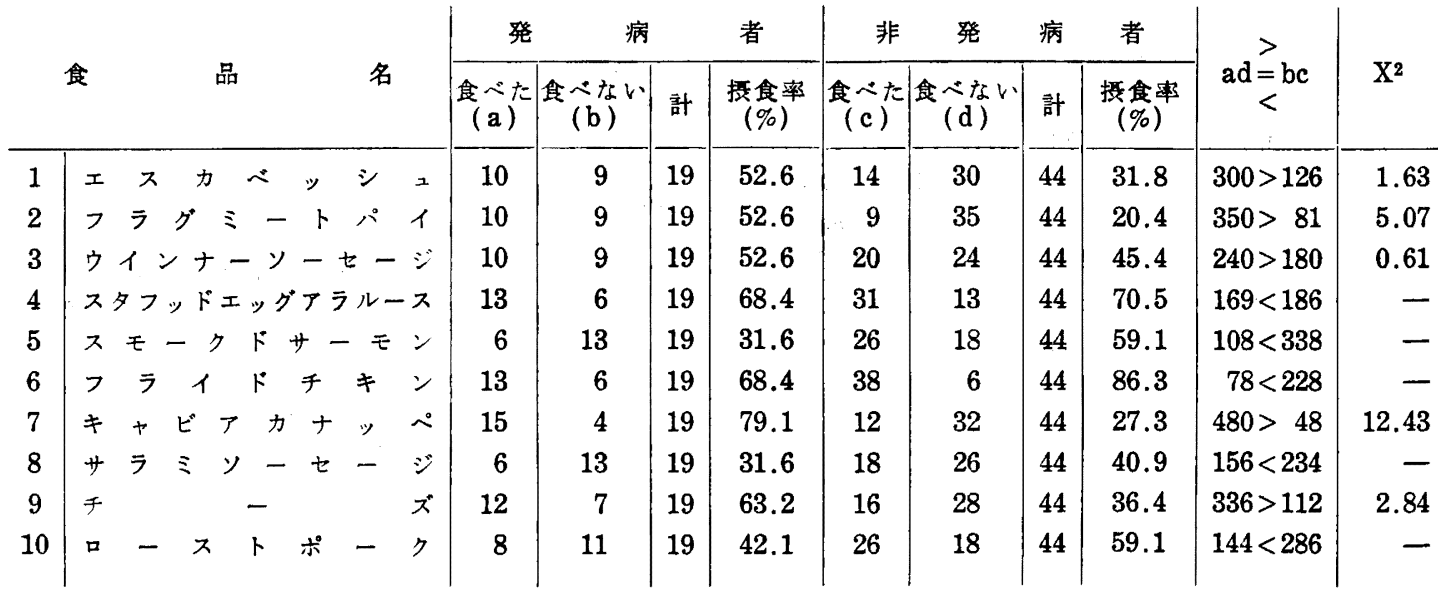


第 2 表 各種検体から毒素・菌の検出状況

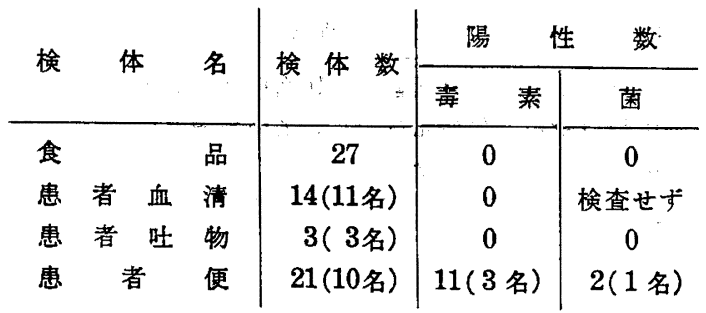

胃腸障害を起こし，1２日経過後ボツリヌス食中毒特有 の複視, 発語困難, えん下障害等の神経麻疸症状が現わ れている (第 3 表).発病率は $32.3 \%$, 死亡率は $14.3 \%$ ， また潜伏時間は最短14時間，最長49時間で平均潜伏時間 は31時間であった。

8. 発生後の経過

千葉県血清研究所より緊急入手した $\mathrm{E}$ 型抗毒素を重症 患者 6 名に使用したが，その後 B 型毒素の検出に成功し たので, さらにB型抗毒素の手配を行ない, 北海道衛生 研究所在庫の AB 型混合抗毒素 2 本の分与を受け, 2 名 の重症患者に注射したが，1名は拒否反応があり途中で 中止した，さらに厚生省の手配でアメリカのレダリー社 より AB 型混合抗毒素20本を取り寄せたが，患者が快方 に向っていたので使用しなかった。なお入院患者は12名 であったが，退院後全員後遺症は残っていない.

9. 措 置

原因食品であるオードブルを調理供食した原因施設は

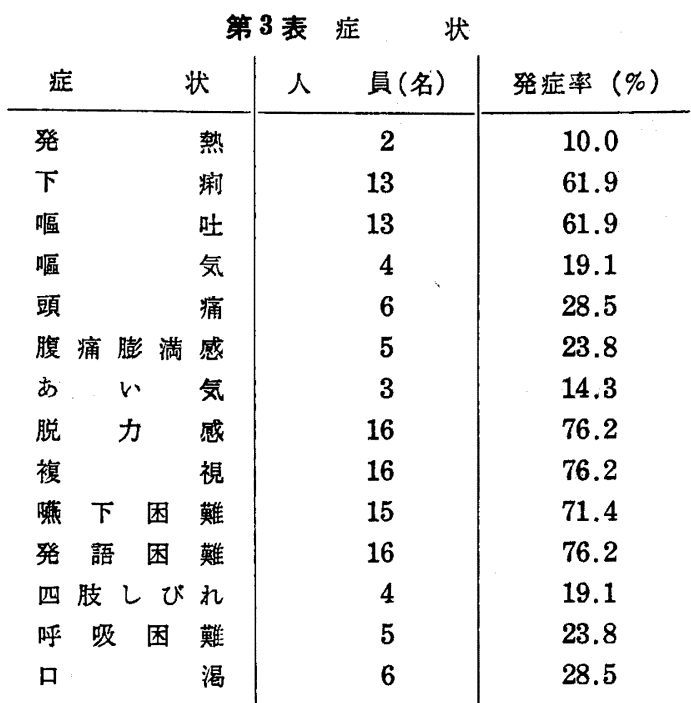

上記の外に眼睑下垂・㯵孔散大・対光反応遅延または 欠如等の症状のあるものもあった。

事件発生後，8月26日から自主的に休業していたが，昭 和44年 9 月 1 日から 15 日まで食品衛生法による営業停止 処分を行ない，施設の清掃消毒，従業員の衛生教育を実 施した。

(宮崎県衛生研究所 北尾忠利)

\section{「削りぶし」によるサルモネラ集団食中毒 (昭和44年10月)}

1. 事件の概要

発生年月日 昭和 44 年10月17日

発生場 所 埼玉県加須小学校

（調理場所：同校給食室）

患 者 数 775名 (発病率78.1\%)

原因食品「削りぶし」あえおひたし

病因物質 Salmonella enteritidis

污染源食品 削りぶし(富山県かね七海産)

措置 加七七海産能谷支店保管

袋詰・散品 計 $3,594,36 \mathrm{~kg}$

焼却処分（11月20日～24日）

2. 事件の発端と患者発生状況

1) 事件の発生状況

昭和44年10月18日，加須市内の 7 医院より計 171 名の 食中毒患者の届け出が保健所にあり，保健所では19日に 一部患者の検便（SS 培地）と調査を開始した。調查は
19日塗抹の培地上集落よりサルモネラ(以下サ菌と略す) 食中毒を疑いながら，給食状況と患者発生状況を調查 し,さらに, 保存食, 原材料および納入業者からの残品を 採取したたらに衛研に搬入，検査を実施した，22日に患 者便，保存食および収去した「削りぶし」より S. enteritidis を分離したので県庁環境衛生課に連絡，同日夕刻 富山県庁に連絡し，「かね七」海産の調査を依頼した。 23日以後県内で販売されている当該社製および他社製の 「削りぶし」を検査し，さらに県内「削りぶし」メーカ 一の工程調查を行なった. 11月20日より当該社製「削り ぶし」の焼却好分をもって本事件は終結した。

2) 患者発生状況と症状発現状況

患者発生は17日午後 3 時頃から20日午後に至るまでみ られ，潜伏時間は最短 3 時間，最長75時間で平均 $25 \sim 29$ 時間であった，発生曲線および症状別発現瀕度は第 1 図 および第 1 表に示すとおりで，特徵は発熱者が多く， 


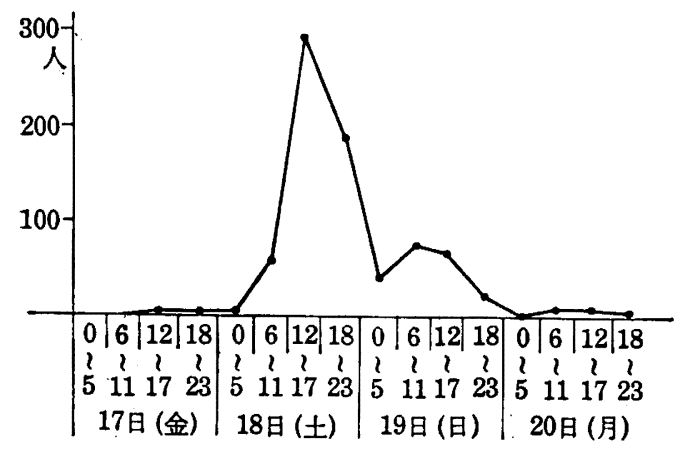

第 1 図日時別発生分布および潜伏時間

第 1 表 症状別発現頻度

\begin{tabular}{rrrr|rrrr} 
症 & 状 & 患者数 & 発現率 & 症 & 状 & 患者数 & 発現率 \\
\cline { 1 - 5 } 下 & 痢 & 592 & 76.4 & 嘔 & 気 & 3 & 0.4 \\
発 & 熱 & 707 & 91.2 & 悪 & 寒 & 220 & 28.0 \\
嘔 & 吐 & 292 & 37.6 & 戦 & 傈 & 9 & 1.2 \\
腹 & 痛 & 511 & 65.9 & 倦总感 & 149 & 19.0 \\
頭 & 痛 & 181 & 23.3 & 脱力感 & 40 & 5.2
\end{tabular}

$40^{\circ}$ 以上 $17.3 \%, 38^{\circ}$ 以上が全体の $81 \%$ を占めた。 下痢 回数は最高 11 回以上 $か 77$ 名 (平均 3.9 回), 嘔吐回数11回 以上が 8 名（平均1.1回）であった. しかし. 調査当初の 症状は，まず頭痛を訴え，発䏶が高いのに比べて嘔吐， 下誗の少なかったことから当初感冒が疑われた。

3）原因食品の推定と調理方法

学校給食に批ける容疑食事の割り出しは困難をきわ め, $\mathrm{X}^{2}$ 検定が効を奏さない場合がある。 今回は第 3 表 に示すような欠席児童の発病関係之特異事例より17日の 「削りぶし」あえおひたしが推定され，さらに，この時 点で患者便からサ菌が検出されたため, 昭和 40 年度の 「青のり」付き塩ゆで馬鈴薯中毒の前例むあり唯一の非 加熱食品である「削りぶし」に容疑をむち，学校に打け る保存食と原材料を収去すると共に「削りぶし」納入業 者の残品について収去と移動禁止を行なった。

調理方法は第 2 図に示すと拈りで, 加須小では調理室 でおひたしに「削りぶし」をあえてから配食したのに対 し, 非発病校の志多見小では, 各教室で契食直前に「削 りぶし」をふりかけて食べている。

この両校の調理方法から,「削りぶし」中の污染廿菌が わずか1 1.5時間たらずで中毒量に達したこと，また， 「削りぶし」中の污染菌量が非常に高かったため, 短時 間で中毒量に達したものと思われる。

4) 病原物質の決定之污染経路追求

患者便よりの菌検出 $64.3 \%$ と保存食（こはくあげお よびおひたし） 2 件からのサ菌検出 $100 \%$ おび原材料 6 件中「削りぶし」を入れて納入した紙袋 1 件からサ菌
篮2表容疑食事の推定

（1） 久席児意からの容疑日推定

$\begin{array}{lll}10.16 \text { (木) } & \text { 欠席児童 } & 10 \text { 名中発病 } 2 \text { 名 } \\ 10.17 \text { (金) } & \text { 欠席児童 } & 8 \text { 名中発病 } 0 \text { 名 } \\ 10.18 \text { (土) } & \text { 非給食日 } & \end{array}$

（2）特異事例

\begin{tabular}{|c|c|c|c|c|c|c|}
\hline & 関 & 係 & 者 & 16日 日) & 17日（金） & $\begin{array}{l}\text { 発病の } \\
\text { 有 無 }\end{array}$ \\
\hline \multicolumn{4}{|c|}{ (新井近衛門（祖父） } & たへない & こはくあげ & 非発病 \\
\hline a & \multicolumn{3}{|c|}{ 新井むめ(祖母) } & たベない & おひたし & 発 病 \\
\hline \multirow{3}{*}{$\begin{array}{l}\text { 用 } \\
\text { 務 } \\
\text { 員 } \\
\text { の } \\
\text { 例 }\end{array}$} & \multicolumn{3}{|c|}{ 新井京子(給食誉) } & サラダ・卵 & $\begin{array}{l}\text { こはくあげ } \\
\text { おひたし }\end{array}$ & 発 病 \\
\hline & \multicolumn{3}{|c|}{ 新井京子の夫 } & サラダ & たベない & 非発病 \\
\hline & \multicolumn{3}{|c|}{$\begin{array}{l}\text { 新井京子の子（幼稚 } \\
\text { 國） }\end{array}$} & サラダ・卵 & たべない & 非発病 \\
\hline \multirow{2}{*}{$\begin{array}{c}\mathrm{b} \\
\text { 持 } \\
\text { 参 } \\
\text { 例 }\end{array}$} & \multicolumn{3}{|c|}{$\begin{array}{l}\text { 須藤奈保美 ( } 3 \text { 年) } \\
\text { 北山の啋 }\end{array}$} & & $\begin{array}{l}\text { こはくあげ } \\
\text { ペソの湖に }\end{array}$ & 非発病 \\
\hline & \multicolumn{3}{|c|}{ (北山繁江（65才） } & & $\begin{array}{l}\text { おひたしし } \\
\text { はさむ }\end{array}$ & 発 \\
\hline
\end{tabular}

（3）摄食状況調查

\begin{tabular}{|c|c|c|c|c|c|}
\hline & こべた & $\begin{array}{l}\text { たへな } \\
\text { い人 }\end{array}$ & 計 & 喫食率 & $\chi^{2}$ 検定 \\
\hline$\underset{け ゙}{こ は く あ ~}\left\{\begin{array}{l}\text { 発病群 } \\
\text { 非発病群 }\end{array}\right.$ & $\begin{array}{l}772 \\
198\end{array}$ & $\begin{array}{r}3 \\
19\end{array}$ & $\begin{array}{l}775 \\
217\end{array}$ & $\begin{array}{l}99.6 \\
90.0\end{array}$ & 48.69 \\
\hline おひたし $\left\{\begin{array}{l}\text { 発病群 } \\
\text { 非発病群 }\end{array}\right.$ & $\begin{array}{l}766 \\
181\end{array}$ & $\begin{array}{r}9 \\
36\end{array}$ & $\begin{array}{l}775 \\
217\end{array}$ & $\begin{array}{l}97.5 \\
83.4\end{array}$ & 92.31 \\
\hline
\end{tabular}

を検出したほか, 納入業者販売店にあった同一メーカー の製造月日の異なる 3 件の「削りぶし」からも菌を検 出し, その菌型決定から S. enteritidis による食中毒 と判定した. さらに，県内販売の当該社製品から50\%に サ菌が検出され，他県製造の検体からはまったく検出さ れなかった。

事件時における当該社製「削りぶし」中のサ菌の污染 菌量は $1 \mathrm{~g}$ 当りの生菌数で, 最低 10, 最高 $3.0 \times 10^{5}$ を 示した．また大腸菌群，E. coli ともに陽性で，腸球菌は 8 件中 1 件のみが陽性であった。ささらに，「削りぶし」中 の菌生存試験では，6 か月経過後も污染菌量はほとん ど変わらず，「削りぶし」等の乾燥物中では長期にわた って生存しらることがわかった。 污染経路については富 山県で実施し, 工場内の原料, 製造器具, 工場内のネズ ミおよび䔬から高率に同菌を検出し，長期にわたって工 場内を累積污染していたことが判明した。

3. 処 置

污染源となった「削りぶし」については，県内小売店 およびかね七海産熊谷支店に保管されていたすべての 「削りぶし」製品を回収した後, 焼却処分とし, 製造所 についての処分は富山県に依頼した。 


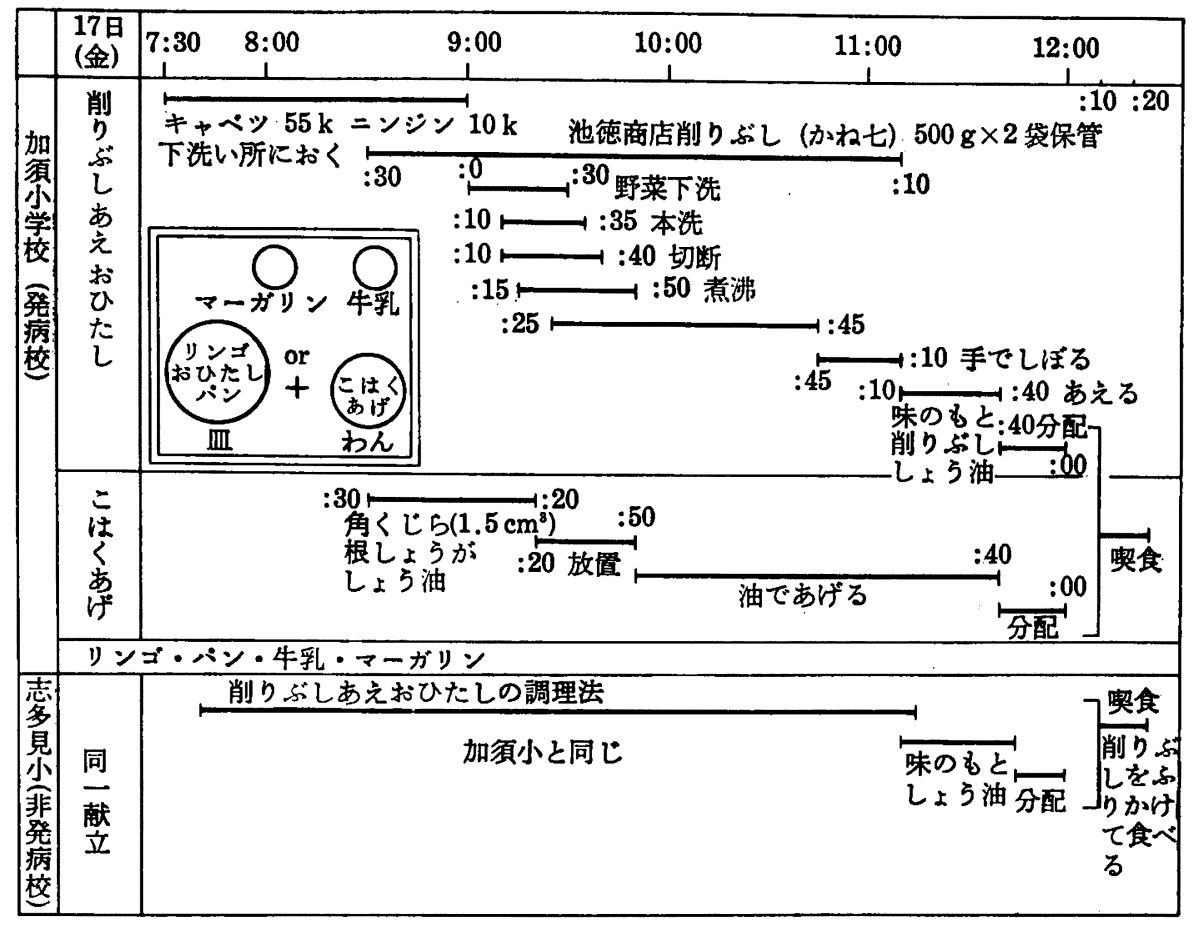

第 2 図原因食の調理方法

さらに，サ菌污染「削りぶし」を用いて，おひたし中 でのサ菌の消長を実験し, 学校給食従事者の衛生教育と 調理献立の検討を指示した。

\section{文献}

日魽会誌。 24, 366 (1971).

(埼玉県衛生研究所 渡辺昭宜)

\section{たまご豆窝による集団食中毒(昭和45年 6 月)}

本食中変事例について行政的な角度で，高田1)が報告 し, 業者, 消費者向けに問題点提起を主眼として井上2) が報告している.

\section{1. 事件の発端}

昭和45年 6 月14日午前11時, 大垣市内某医院より, 名 神䇾ら隊員 3 名が 6 月13日夕食の仕出し弁当で発病した とみられる食中毒患者を診断した旨通報があった。ただ ちに仕出し業者を中心に調查を開始した結果，大垣市， 関ヶ原町など西泿地域一円に食中串患者の続発をみ，共 通原因食品はたまご豆腐であることがきわめて迅速に確 定した.

\section{2. 発生概況}

患者は 6 月13日〜17日にわたって発生し，患者数 415 名 (死亡 2 名)，そのうちの231名 (56\%) は6月14日に 発生している. 患者発生を地区別にみたものを第 1 表に
示した．岐阜県内と滋賀県の一部は主に店頭購入摄食患 者であり,その他の府県の患者は大垣市とその近郊で会 議, 法要などに参加, 喫食罹患したものである. 大垣市 内と大野町では原因食たまご豆腐は食べていないが，調 理器具などを介して二次污染した食品を篹食して発病に 至った患者 (間接污染) が 101 名あったことが特徵とな っている.

潜伏時間は摄食時刻(13日冝食, 夕食, 14日冝食, 夕 食）が幅広いためか $6 \sim 46$ 時間にまたがり, 患者 310 名 の平均潜伏時間は16.9時間であった。なお，たまご豆腐 喫食患者と間接污染患者との間には特に潜伏時間に羑異 は認められなかった。

3. 臨床症状

主要症状を第 2 表に示したが，直接たまご豆腐を梨食 したものと間接污染患者との間には相違がみられなかっ 
第1表 地区別患者登生状況

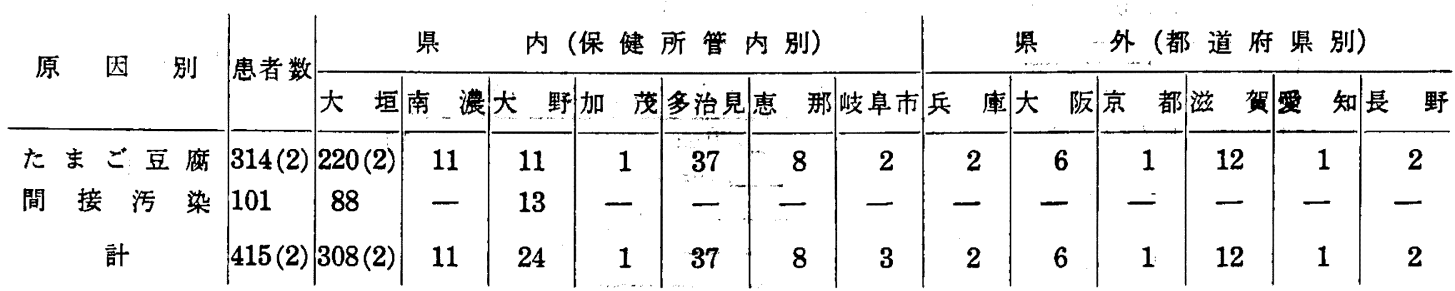

注（）内死者数 たまご豆腐，二次污染食品䒜食者，554名，慨患率 $56.6 \%$

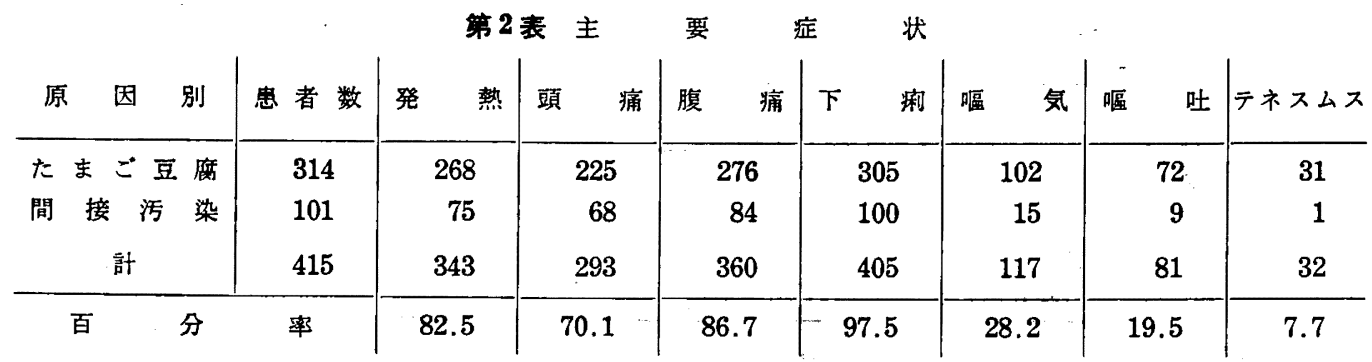

第 3 表 検 便 状況

\begin{tabular}{|c|c|c|c|c|c|c|c|}
\hline 対 & & 象 & 検 查数 & 陽性 数 & 百分率 & 備 & 考 \\
\hline 患 & & 者 & 105 & 55 & 54.2 & & \\
\hline 患 & 者 家 & 族 & 381 & 2 & 0.5 & & \\
\hline 取 & 扱 & 者 & 254 & 14 & 0 & 八百屋, スーパー, 仕出し業など & \\
\hline 市埸 & 場従業 & 員 & 44 & 0 & 0 & （水）市場，（海）市場 & \\
\hline 鶏 畉 & 留 卸業 & 者 & 24 & 0 & 0 & 生卵, 液卵取扱業者 & \\
\hline & 計 & & 808 & 73 & 9.03 & & \\
\hline
\end{tabular}

陽性: S. montevideo 検出

た. 大垣保健所管内患者 308 名中52名が入院加療, $4 \sim 12$ 日で全治退院しているが，病後排菌追跡調査では $35 \sim 50$ 日の長期間排菌していたものがかなりあった。

\section{4. 細菌検查}

患者とその家族, 食品業者などの検便実施状況を第 3 表に示したが，患者とたまご豆腐を取り扱った調理人の みにS. montevideo剠検出された. なお，患者吐物 2 例中 1 例からもS. montevideo を検出した.

一方，原因食となったたまご豆腐 19 検体中 16 検体に S. montevideo が検出され，その菌数はほぼ100万〜290 万/gであった。一般細菌数もきわめて多く 7,700 万〜 40,000 万/g で，製品の保存管理が不十分であったと思 われる.

原因食たまご豆席，患者，吐物などよりの分離株 47 株 の薬剤耐性ハシターンは同一の傾向を示し, SM, CP, TC, $\mathrm{KM}$ などに強い感受性を示した。

5. 污染経路

原因食たまこ豆腐からのS. montevideo の検出状況
罹患率などから多数のたさご豆腐のサルモネラ污染の経 路を重点的に調査した. 製造者 (岐阜県翊老郡養老町) と その家族 4 名の検便で增菌培着によって 5 名中 4 名から S. montevideo を検出した。製造者はたまご豆腐を䊬食 しているが，その他のものは契食していないにむかかわ らず, S. montevideo が検出されたのは注目に值する.

製造者は 4 月上旬の業態者検便では異常を認めていない が, 4 月下旬に下琍を主訴とする疾病で治療 (C.P. 投与) を受けていた。

製品出荷後の流通過程での污染の可能性は少なく, 原 料液畉とその取扱業者, 慆卵生産者からはサルモネラは むちろん, 既知病原菌は検出されなかった。

事件直後, 調理場はすでに清摛されており，ふきとり 試験では何も得るものはなかった。 しかし調理場に残存 していた原料液卵（6月12，13日仕入液卵の混合？）絮 5S. montevideo が検出された. 分離株で污染させた 液卵（サルモネラ 40 万 $/ \mathrm{g}$ ) を用いた模擬製造テストでは 接種菌はすべて死減しており，加熱操作 $\left(80^{\circ} 20\right.$ 分) に俱 
りはなかったと推定される．したがって，たまご豆腐の 出来上り後の放冷, 成型, 包装工程に污染の機会があっ たものと推定される.

6. むすび

（1）たまご豆腐自体がきわめて好適な細菌培善基で あり， 1 個 1 個の包装が直接手の触れる手作業でなされ た. 調理場にサルモネラ污染が推定されたことから，污 染たまご豆腐が市場，小売業者への輸送が冷蔵翰送の配 虑なしに一般食品と同一に取り报われた。

（2）製造能力を越える受注生産のため，製造工程時
間が長引き，保管冷藏設備の不足をきたし，製品の衛生 的な取り扱いに欠けるところがあった。

（3）たまご豆腐のような食品は自家製造されるべき 食品であり, 安易なインスタント食品化への風潮を戒め るともに，行政当局の適切な監視と指導が必要である.

文献

1）高田三郎：食品街生研究 21，102(1971).

2）井上裕正：食品街生 14，60 (1970). (岐阜県衛生研究所 後藤喜一)

\section{グルタミン酸ナトリウムの多量㠌取 \\ による食中毒 (昭和46年 3 月)}

\section{1. 事件の発端}

昭和46年 3 月頃から，味付こんぶを食べたところ間も なく，灼熱感，顏面の王迫感，僚总感などを引き起こし たといら苦情の届け出が都内各保健所に相継ぎ，一年で 11件に及んだ．また中華料理でも同様の症状の訴えが 2 件起こった.

2. 患者の発生状況

苦情者よりの訴えおよび度学的調査によると，性別， 年令に関係なく中害は発生し，いずれの場合も，10時ま たは 3 時の空腹時に味付こんぶをお䒩または水と共に食 べている，第 1 表のよ5に喫食後 5 ３0分で発症し， ほ とんどの人が一過珄で, 発生後 $1 \sim 2$ 時間で回復してい る. また症状は顔面の圧迫感，ほほから後頭部および首 筋へのしびれや鈍痛, 灼熱感, 手足のしびれが主症で時 には吐気またはアルコール様酩酊感および倦怠感などの 末梢神経症状を呈するが，胃腸障害はみられない．また 発症率は第 1 表に見られるよらに高く一年間で50人にお よんた。

3. 原因物質の追求

この一連の中毒は，これらの調査結果から化学性物質 が原因であると推定されたので，まず味付こんぶの製造 法を調查し，それに使用されている人工甘味料，有機酸 などの食品添加物, 混入の疑われる有害性重金属類, さ らにコンブの品質を知るためにナトリウム, カリウム, カルシウム, ヨウ素および塩素イオンなどの無機成分, 遊離アミノ酸の天然成分などについて，中残品および 参考品を対象に検查を行なった. その結果, クルタミン 酸の量が異常に高く，またナトリウムの量も普通の味付 こんぶよりはるかに多いことが判明した。

第 1 表に見られるよらに中毒残品および参考品中のグ ルタミン酸モノナトリウム（以下M Gと略す）の量は 最高約 $45 \%$ ，最低でも $13 \%$ と異常に多量に含まれ，さら
に表面の粉末を分析すると，そのほとんどが MSG であ り, 中には95 98\%と純度の高いものもあった.これら 味付こんぶを苦情者が食べたと推定される量から MSG 摄取量を換算すると，多い人で約 $14 \mathrm{~g}$ ，少ない人で約 $2 \mathrm{~g}$ 食べていることが判明した，また中華料理でも同様に多 量の MSG が使用されていた. このような検查結果や当 研究室で残品および MSGを撕取したところ，そのうち の若干名に苦情者と同様の症状が再現できたこと,さら に文献的探索などの総合的調查結果から,この一連の中 毒は, MSG 多量摄取による, いわゆる “Chinese restaurant syndrome” (以下 CRS と略す) であると認めた。

CRS とは，1968年 Kwok ${ }^{1)}$ が中華料理店で食事した 後で経験する特異な症状を CRS と名付け New. Eng. J. Med. に書簡を寄せたことに端を発している.この報 告によると, 契食後 15 20 分で灼熱感および王迫感が こめかぬおよび首筋さらに腕から胸部へと放射状に広が ってゆき,この状態は 1 2 時間続いた後消失する一過性 の症状を呈するとされている. またその後 Schaumburg らはこの原因物質がグルタミン酸であると発表し，さら に多くの人により人体実験がおこなわれ(),5)，グルタミ ン酸の多量摄取により特定の人が発症し, その量には個 人差が相当みられるが，一般に 3 5g で発症するとさ れ6), 発症時間は喫食後 $5 \sim 30$ 分とされている. 発症理 由についてはいくつか報文むあり，フセチルコリン説》 が有力であるが，現在までのところ不明で，わが国では 田所 $5^{8), 9)}$ が行動薬理的実験から中权珄であることも疑 われるといっているが今後の研究にまたれる.

4. 対策と好置

このよらな MSG の多量使用の事実が判明したため, 昭和46年10月に味付こんぶや 中華料理について，MSG の使用量実態調查を行なった. その結果味付こんぶでは 43 検体中27検体が30\%以上の MSG を検出し, 天然含有 


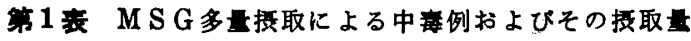

\begin{tabular}{|c|c|c|c|c|c|c|}
\hline 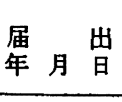 & 品 & 発症率 & \begin{tabular}{|c|} 
発症まで \\
の時間 \\
(分) \\
\end{tabular} & 症 & MSG 含有目 $(\%)$ & $\begin{array}{c}\text { MSG 接取五 } \\
(\mathrm{g})\end{array}$ \\
\hline 46. 3.11 & 酢 $こ$ s & $5 / 10$ & 数 分 & 悪心, 矓量 & - & - \\
\hline 46. 4.26 & $n$ & $2 / 2$ & - & 顔面の圧迫感 & - & - \\
\hline 46. 6. 8 & 結 びこんs & $5 / 5$ & $20 \sim 30$ & 頭痛, 首筋の倦态感 & 残 品 13.3 & 多、人 3.3 \\
\hline 46. 6.29 & $n$ & $3 / 3$ & 30 & 頭部重圧感, 全身供态感 & " 32.6 & 平均 4.3 \\
\hline 46. 8.17 & $n$ & $11 / 11$ & $10 \sim 30$ & 倦念感, 眩量, 吐気 & 27.5 & " 6.9 \\
\hline 46. 8.18 & 中華野菜スープ & $4 / 4$ & 5 & 手足のしびれ, 胸苦しい & 参考品 $\quad 1.5 \mathrm{~W} / \mathrm{V} \%$ & 4.5 \\
\hline 46.10 .14 & 結 びこんぶ & $4 / 4$ & $10 \sim 20$ & 顔のしびれ，眩量，吐気 & 残 品 32.5 & 8.9 \\
\hline 46.11. 8 & 板 状こん & $4 / 4$ & $5 \sim 10$ & 顔から首にかけてこわばり感 & 参考品 37.2 & 5.1 \\
\hline 46.12 .24 & " & $2 / 2$ & 30 & 顔のしびれ，吐気，脱力感 & 22.4 & 6.4 \\
\hline 47. 1.4 & 中華バイキング & $5 /$ & - & 舌のしびれ，眠気 & $" \quad \pi-フ ゚ 2.3 \mathrm{~W} / \mathrm{V} \%$ & $" \quad 2.0$ \\
\hline 47. 1.20 & 結 びこん ふ & $1 / 3$ & 10 & 激しい後頭部のしびれ & 残 品 40.9 & $\begin{array}{l}\text { 多い人 } 14.3 \\
\text { 少ない人 } 7.2\end{array}$ \\
\hline 47. 1.6 & $"$ & $2 / 2$ & 直 後 & 後頭部のしびれ, 手足の椧感 & 参考品 45.3 & $\begin{array}{l}\text { 多い人 } 13.6 \\
\text { 少ない人 } 8.2\end{array}$ \\
\hline 47. 2.28 & " & $2 / 2$ & $20 \sim 45$ & 悪心, 後頭部のしびれ & 残 品 22.0 & 平均 2.2 \\
\hline $47,8.17$ & 中 華 料 理 & $2 / 8$ & $10 \sim 20$ & 顔面のしびれ，けいれん & $\begin{array}{r}\text { 参考品 } \\
1.2 \mathrm{~W} / \mathrm{V} \%\end{array}$ & $\begin{array}{ll}" \prime & 4.5 \\
" & 3.6\end{array}$ \\
\hline 48. 4.3 & 結 びこんふ & $1 / 2$ & 10 & $\begin{array}{l}\text { 口周辺のしびれ, 手育の柽い } \\
\text { けレれん }\end{array}$ & 残 品 22.8 & 3.0 \\
\hline 48. 6.27 & 中 華 料 理 & $2 / 2$ & 直 後 & $\begin{array}{l}\text { 䫓のこわばり感, ひざのカが } \\
\text { 抜ける感じ }\end{array}$ & $\begin{array}{r}\text { 参考品スープ0.3W/V\% } \\
\text { えび甘酢竟0.1 }\end{array}$ & 2.0 \\
\hline
\end{tabular}

量 (0.2 5\%) をはるかに上回り, また中華料理では, $1_{3}$ 軒32検体を調查した結果，一食分で最高 $10 \mathrm{~g}$ を，なた $1 \mathrm{~g}$ 以上のものが 7 検体あり，本来の目的である調味に 使用する量をはるかに上回る使用実態が判明した.

このような味付こんぶの出廻った理由について, 都衛 生局で調査したところ，コンブが昭和46年 3 月頃から値 上りしたため, コンブより安価な MSGを一部メーカー が増量の目的で使用していたことがわかり，これら調查 結果について厚生省に報告し，また MSGに対する使用 基準がないため，その善処方を申し入れたところ，同様 な中害例の報告が昭和46年 $3 \sim 4$ 月に佐賀県 1 件, 福岡 県 2 件あり，厚生省では昭和 47 年 1 月味付こんぶ製造業 者に対して $3 \%$ 以下の添加に止めるよう行政指導を行な った. その後厚生省でも調査を行ない, 都と同様の結果 を得たので，厚生省から各地方庁へ，食品製造加工業 者, 飲食店営業者等に対し, MSG を必要以上に使用し ないよ5十分指道し, 事故発生等の防止につとめるよう 通達が発せられた。

なお，47年 4 月以降第 1 表のように味付こんぶおよび 中華料理による中毒が件発生している.

5. と め

一般に安全と認められている MSGでこのよらな事故 が発生したことは, 食品製造業者のモラルに関与すると ころが大きいが，使用基準のない合成食品添加物や天然 添加物に対して, 十分な指導, 監視, 使用量のチェック
等を行ない，また使用基準の設定について，さらに検討 する必要性があると考える.

なお，事故例と実態調查，MSG と人の感受性および MSG 多量摂取による人体内各種成分の変動については それぞれ第24回，第25回日本食品衛生学会に発表してあ るが, 発症機構の解明については, 現在, 検討を続行中 である。

\section{文献}

1) Kwok, R. H.: New Eng. J. Med., 278, 796 (1968).

2) Schaumburg, H.: ibid, 279, 105 (1968).

3) Schaumburg, H., Byck, R. et al.: Science, 163, 826 (1969).

4) Ambos, M., Leavitt, N. R. et al.: New Eng. J. Med., 279, 105 (1968).

5) Rosenbluml, Bradley, J. D. et al.: Toxicol \& Appli. Pham., 18, 367 (1971).

6) Kenney, R. A., Tidball, C. S.: Am. J. Clinical Nutr., 25, 140 (1970).

7) Ghadimi, H., Kumar, S. et al.: Biochem. Med. 5, 447 (7971).

8) 田所作太郎, 樋口洋一郎：第47回, 日本薬理学会 関東部会講演要旨

9）田所作太郎，桶口洋一郎：第48回日本薬理学会関 東部会請演要旨

(東京都立徫生研究所 西垣 進・田村行弘) 


\section{アメリカチョウセンアサガオによる中毒 (昭和46年 3 月)}

\section{1. 事件の発端}

昭和 46 年 3 月21日～22日にかけ，てんふらら, 煮つけ等 を家族 7 名が揸食したところ，6名が掑食後約 30 分頃か ら相次いで視力減弱, 歩行障害, 瞳孔散大などの中毒症 状を呈した.さらに手伝いに来た親戚の者 2 名が24日ご ぼうの煮つけによって同様に発症し，近くの診療所に入 院した旨の報告が 3 月26日にあった。

\section{2. 発生日時拉よび場所}

昭和46年 3 月21日 3 月24日, 愛知県宝飯郡音羽町

\section{3. 発生経緯}

家族 7 名のらち 5 名が 3 月21日の夕食のために調理し たごぼらのてんぶらを 1 個〜 2 個摂食し, 中毒を起こし た.しかし，残りの 2 名のらち 1 名は翌22日の昼食にご ぼらの煮つけを食べたところ，同様に中毒し，手当を受 けた. 1名を残して中毒症状を呈したため，介抱，手伝 いに来た親戚の 2 名まです24日朝, ごぼうの惹つけを食 ベ中毒を起こしてしまった，中毒患者はいずれもごぼう を摂食したために中毒を起こしていることから，食べ残 りのごぼらのてんぷら，著つけをはじめ，調理に使用し た小麦粉, 油, しょらゆなどが検査品目として持ち込ま れた，中毒症状では，下誗，腹痛などはなく，細菌性の 中弯ではないと思われた。このため，䓯物の混入による 中売ではないかと思われたため, 各種農薬類, 重金属類 を検索したが，いずれも中毒量とはほど遠い微量であっ た. 原因物質として間違いないと思われるごぼらについ ては, しばらく後に，まだ末調理のものが入手できた。
このごぼうの中に，一見してごぼうと形がよく似ている が，他の植物のものと思われるやや黄かっ色を呈した根 が入っていた。この問題の根をむとに,てんぶら, 煮つ け等を同様に詳細に検索したところここぼらを用いた検 体からはいずれる薄層クロマトグラフィーにより，フル カロイド呈色試薬で陽性のスポットを確認した。 な抽, ごぽう（食用）からは同一のスポットは確認できなかっ た.

\section{4. 規 模}

患者：3月21日夕食ごぼうのてんぶらを摄食した者 5 名（男44才，16才，女38才，18才，13才）22日昼食ごぼ 5の煮つけ摂食者 1 名（男92才），24日朝食ごぼうの煮 つけを摄食した手伝いの者 2 名（女61才，68才）合計 8 名, 発症率: いずれもごぼうの調理食品を摂食した者で $100 \%$ ，死亡者はなかった。

5. 原因物質

ごぼうの根とよく似た形の植物の根による中童である と推定されたため，この根とてんぶら，煮つけを詳細に 検索した結果，いずれの検体からもアトロピンが検出さ れた. 患者の中症状もアトロピンの特異的な作用とほ ぼ一致した。 アトロピンを含有する植物はダッラ属の植 物があげられるが，その後の調査で患者の家で以前，花 が大きく，きれいな植物であるチョウセンフサガオを栽 培したことがあり，ごぼうをその場所に保存のために一 時埋めこんでおいたといらことからごぼうを掘り出すと き誤まって一緒にチョウセンフサガオの根まで掘り出し

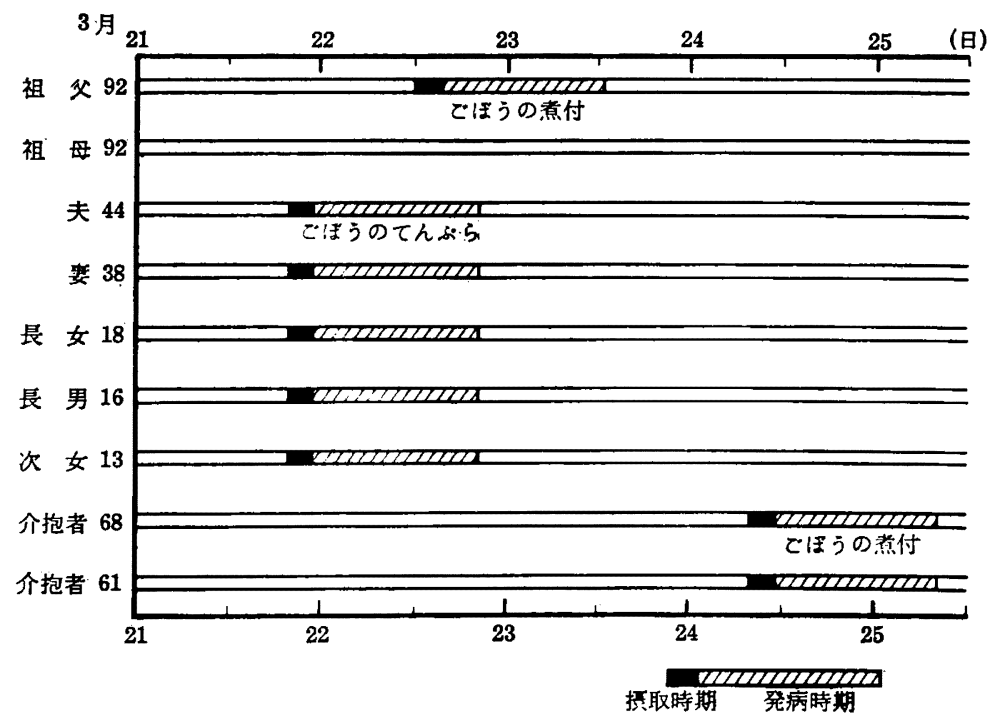

第 1 図攝食および発病時期 


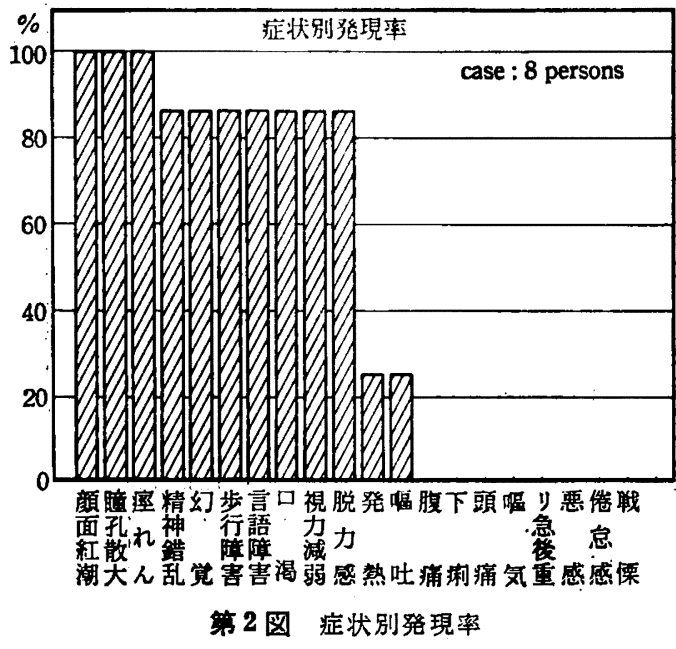

てしまったと推定され一緒に調理したために中毒を起こ
したものと思われる.

6. 症 状

いずれもフトロピン様の作用で，初期にのどのかわき 足のもつれ, 視野狭窄, 精神錯乱等を呈している.

7. 発生後の経緯

患者はいずれもごぼらの調理食品以外では中毒せず， アトロピンによる強力な作用は医師の胃洗浄, 強心剂な どの注射による適当な治療によりほぼ24時間後にははと んど回復している.

8. その他

検体として持ち込まれた原因植物の根（親指大）が比 較的新鮮であったため，水分を与えて栽培したところ， 数日後に芽を出し, 翌年春, 長さ $20 \mathrm{~cm}$, 直径約 $10 \mathrm{~cm}$ のラッパ状のらす紫色の花をつけた. 花のあと, 直径約 $3 \mathrm{~cm}$ の蒴果を生じ, 円形扁平な種子が多数含まれてい た.これらはダッラ属植物に共通しており，アメリカチ ヨウセンフサガオ（Datula meteloides）と推定した.

(愛知県衛生研究所 河村典久)

\section{小笠原海域採捕魚による中毒(昭和46年12月)}

\section{1. 事件の発端}

昭和 46 年 12 月 17 日から翌年 1 月上旬にかけて「クエ」 と称して市販されていた魚の「切り身」を水欣きして44 名以上が摄取し，らち麻疸，脱力感などを主症とする42 名の患者が 発生するとい58 件の 食中毒事件が 発生し た。

昭和46年12月19日, 16時から20時頃の間高知市舛 勝賀 瀬敏夫宅で 9 名が忘年会を催し，その際「ハタ」,「クェ」 の水饮き料理を摄食して約 $2 \sim 6$ 時間経過の後, 下淿, 脱力感, 麻疸を訴え，翌朝届け出たものである.

魚の調理状況は魚体 $3.5 \mathrm{~kg}$ のらち $2.7 \mathrm{~kg}$ を 1 個の鍋 に $0.9 \mathrm{~L}$, さらに追加分として途中から $0.9 \mathrm{~L}$ を加水し ハクサイ, シュンギク, 七リ, 豆腐, 生シイタケ, ネギ 等の野菜類と一緒に煮たもので, 各人はダイコン, とう がらししょら油，酢，橙酢を混ぜた「タレ」につけ 2.7 $\mathrm{kg}$ のらち約 $1.9 \mathrm{~kg}$ がほぼ均等に摄取されており, 残 品 $0.8 \mathrm{~kg}$ が確認され, 萻物抽出の試料とした.

本件が今回の食中書事件の発端で以下 7 件が新聞報道 などで知られ順次所轄保健所に届け出されて全ぼらが判 明した。

原因魚の調理, 摂取方法等はほぼ同じで水炊きしてお り特別に異なった方法のものはないささらに中毒を起こ した魚の入手経路は小笠原海域で採捕されたものを静岡 県沼津港経由陸送で荷受け機関の水産会社が買受け市場
に出されたもので，12月25日頃から数回販売されている が詳細は不明である.

2. 症 状

全員がまったく同一の症状で若千の軽重の差が認めら れたが，捄むね次のよらであった。 (1)下浰：最初の症 状は必ず下浰 (軟便, 下浰) で細菌性下利のよらに激し いものでなく期間は1～2 日で亭止し速やかに正常便に 復した. (2)脱力感：身体は極端にけん怠感を覚え，とく 両肢のふくらはぎの部分, 全身の関節のだるさと麻疩を に覚えた。 (3)疲労感：心贜作用し，血圧の下降をみた。 少しの運動たとえば階段を10段程度昇っても動悸が激し くふらふらした. (4)皮瓦の感覚は常時冷たい感じで，ま た肌がときどき痛いような感覚があり，廊下を频いても 痛みを感じた。 (5)眼瞼の反応 : 眼は2 2 日後にアレル ギー疾患にあるよらに眼瞼を半開きにしてしょ注しょ注 し，さらに眼球が落ちくぼんだような感じがした。 (6)そ の他: 腹痛, 発熱はほとんどないが人によって嘔吐, 嘔 気, 悪感があった.

\section{3. 原因物質の確認}

残っていた魚肉から, 食品衛生検查指針[1]の方法で 每物の抽出を試み, マウスの腹腔内注射を行ない, 病原 性の程度 (M. U.) とその状態を観察し,ささらに魚を用い て約 $1 / 3$ に涱維したものに米飯若干量を加え, イヌに経 口投与した結果, 約 20 時間後に四肢に麻㽻, 流涎等の症 
第 1 表 患者数と潜 伏時間

\begin{tabular}{|c|c|c|c|c|c|c|c|}
\hline $\begin{array}{l}\text { 事件 } \\
\text { 番号 }\end{array}$ & 事件の発生場所 & 発生年月 日 & 掫食者数 & 患 者 数 & 受診者数 & 潜伏時間 & $\begin{array}{c}\text { 原因食品 } \\
\text { (魚種名) }\end{array}$ \\
\hline 5 & 香美郡香北町門田○○子方 & 昭和 46 年 12 月 17 日 & 8 名 & 8 名 & 3 名 & $9 \sim 12$ 時間 & アシキガンモ \\
\hline 6 & 長岡郡本山町小松紀○方 & $" \Rightarrow 18$ 日 & 10名 & 8 名 & 8 名 & $5 \sim 48 "$ & 不明 \\
\hline 1 & 高知市外形勝賀瀬○○方 & " $" 19$ 日 & 9 名 & 9 名 & 3 名 & $2 \sim 6 \quad$ & バラ八タ \\
\hline 8 & 高岡郡佐川○村岡遊○子方 & $" \quad 21$ 日 & 4 名 & 4 名 & 4 名 & $2 \sim 3$ & 不 \\
\hline 2 & 高知市○本町真島○子方 & $n \quad " n 30$ 日 & 3 名 & 3 名 & 3 名 & $3 \sim 5 \quad \prime \prime$ & $"$ \\
\hline 3 & 高知市北 ○町大音○久方 & $n \quad " \quad 29$ 日 & 3 名 & 3 名 & 3 名 & 直 & $"$ \\
\hline 4 & 高岡郡佐○町上田 $\bigcirc$ 義方 & $n \quad " \quad 31$ 日 & 6 名 & 6 名 & 2 名 & 間 & $"$ \\
\hline 7 & 高知市西洋町神崎 $\bigcirc$ 幸方 & 昭和 47 年 1 月 1 日 & 1 名 & 1 名 & 1 名 & 間 & $"$ \\
\hline & 計 & & 44名 & 42名 & 27名 & & \\
\hline
\end{tabular}

注 不明魚は「切り身」のため魚種不明となっているが, 眅売した小売店で写真を見せ, 南方海域産の魚であ ることを確認した。

第 2 表 魚類に認められた Ciguatera-type toxin

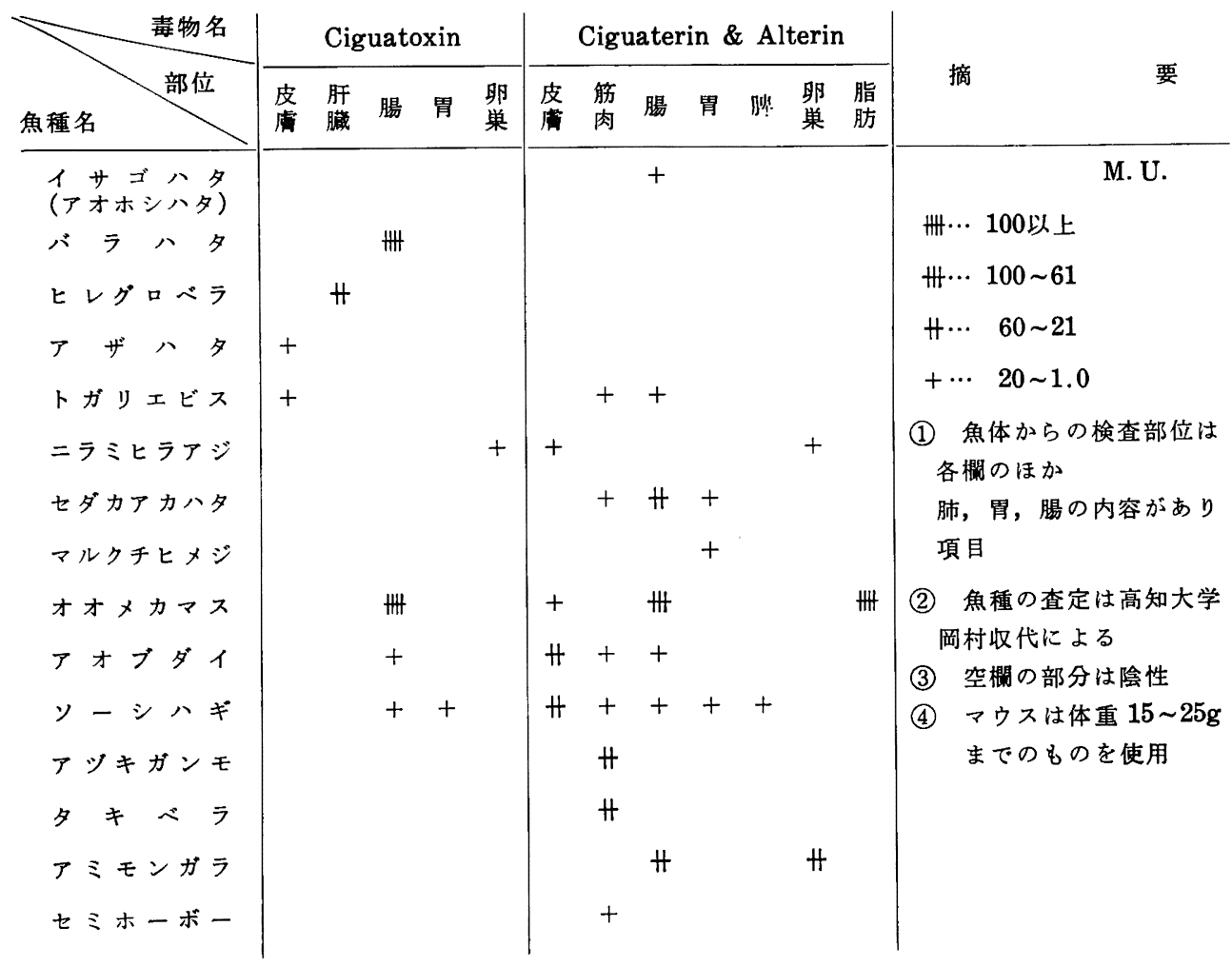

状を呈することを確認した。

4. 魚市場に淤る魚類のシガテラ型毒保有魚の検出 状況

本事件以後, 保健所では管内の中央卸売市場と協議上 場された魚類について Ciguatera-type toxin につい
て, 橋本，土屋氏等の著書を参考として抽出を試みたと ころ上に示すような結果を得た。この種の病原性確認の 試験にはネコが最も郎いとされているがなかなか入手は 容易でないのでマウスを用いて (M. U.) を算出した. (高知県中央保健所 伊与田 清) 


\section{ヨウシュチョウセンアサガオによる中毒 (昭和47年 4 月)}

\section{1. 事件の発生とその症状}

昭和 47 年 4 月 21 日, 群馬県沼田市において, 雑貨商を 営んでいる61才の主婦が庭先から掘り出したゴボウ様根 菱をキンピラに調理し, 午後 1 時頃副食として昼食をと った。約 30 分後から，目まい，口渴，脱力感および運動 失調を呈した. 摂食後 1 時間頃から,おこりっぼくなり, たんすを何回も開閉したり，目的もなく物を探したり， 客がいないのにつり銭を出したりする行動が目立ったの で，発狂したとして親戚の者 7 名が呼び集められた。 お りしも, 夕食時に当たっていたので午後 8 時頃このきん ぴらで会食したところ, 間もなく 3 名が同様の初期症状 を呈し、はじめて食中毒であることが判明した。患者は 24〜64才，男 5 名，女 3 名，計 8 名であった。

中毒患者の症状

初期 (30 60分) 一一口渴, 中等度の散噇, 皮膚紅潮, 脱力感等の副交感神経様症状.

中期 $(60 \sim 120$ 分 $)$ 一一不安, 不稳, せん妄錯視, 幻覚 記憶喪失等の精神症状.

終期 (120〜）—24時間で徐々に回復，きんぴら 摂取量と症状の強さおよび経過時間 との間に平行関係が認められる.

2. 有毒根茎による動物実験

(1) 根茎投与実験
約 $1 \mathrm{~cm}^{3}$ の本根片を数個慨のかわりに 5 匹の DDN 系雄成熟マウスの飼育箱中に夕刻投入し翌朝観察したと ころ, 3 例はすでに死亡, 残り 2 例も振せんや間代性痤 攣を示し衰弱していた。

(2) 根茎抽出物投与実験

根茎 $20 \mathrm{~g}$ を乳鉢中で蒸留水 $10 \mathrm{ml}$ と共に十分細研し， ガーゼろ過し, かっ色の水性抽出液を $26 \mathrm{ml}$ 得た. 本液 を上記条件のマウス 5 匹に $0.5 \mathrm{ml}$ ずつ経口投与した．投 与後マウスは一時鎮静したが, $15 \sim 30$ 分後には瞳孔が散 大し, 外部刺激に対し敏感かつ攻撃的となり, しばしば 軀幹筋群の痙拿が起こった。 1 例のマウスは約 1 時間後 に間代性痤挙を示し死亡したが, 他の 4 例はすべて24時 間後には回復した，また同液 $3 \sim 5 \mathrm{ml}$ をWistar 系成熟 雄ラットに経口投与した場合，5 分後には散瞳が認めら れ，15分後には最大となったが，全身症状は軽度であっ た. また根茎 $20 \mathrm{~g}$ をエタノール $10 \mathrm{ml}$ と共に細砕, ろ 過後蒸発乾固したのち蒸留水 $10 \mathrm{ml}$ 加えた液を $0.5 \mathrm{ml}$ ず つマウスに経口投与した際の症状も上記水性抽出液投与 時とほぼ同様であり，5 例すべて生存した。

（3）モルモット摘出腸管に対する水性抽出液の作用 (Magnus 法)

$2 \times 10^{-8}$ の acetylcholine適用時に一定の収縮高を示す ことが確認された摘出モルモット回腸に対し, 本根茎水

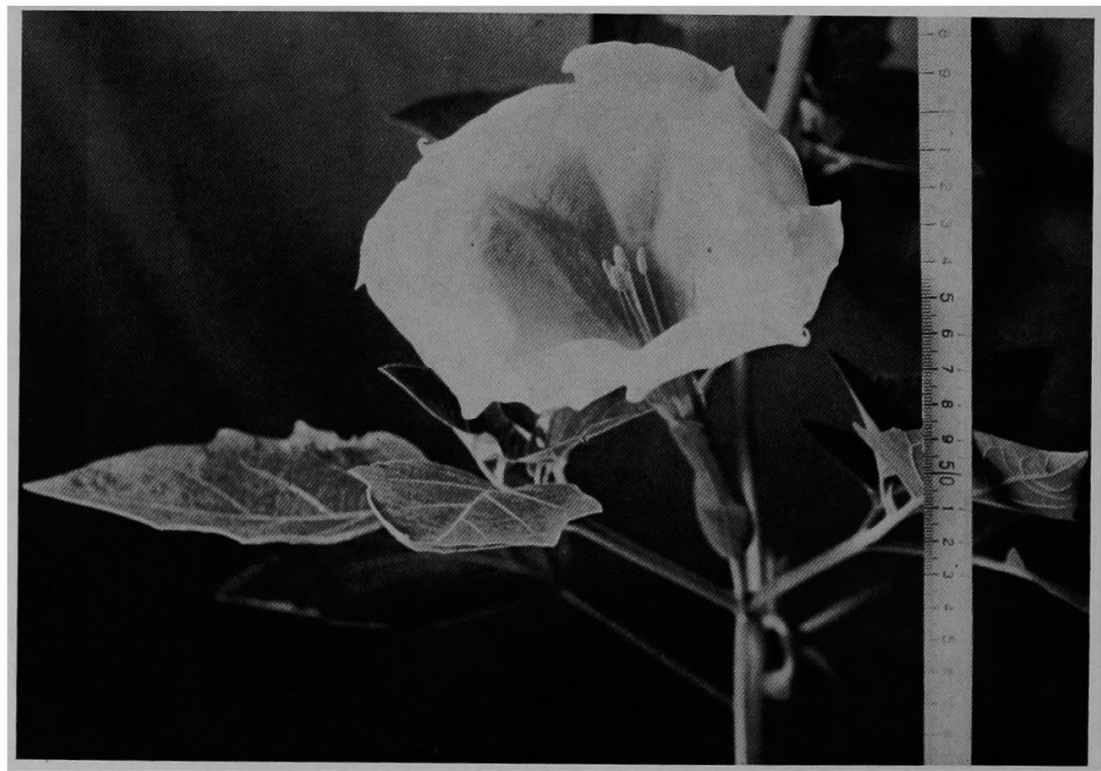

第 1 図中毒原因となった根茎栽培によって開花したヨウシュチョウセンアサガオ 
性抽出液の $10^{-2} \sim 14^{-4}$ を添加すると, 著明な弦緩効果 を示した。この効果は atropine 10-6 10-10 添加時と 同様であり，抽出液中には atropine よ5物質が含有さ れているものと推定された。ささらに各種㴚度の本抽出液 および atropine 前処直によって起こる acetylcholine 適用時の収樎抑制度から，抽出液中の atropine よう物 質を生物学的に测定した結果，本根茥 $1 \mathrm{~g}$ には，約 $500 \mu \mathrm{g}$ が含有されていると考えられた.

3. 原因物質の同定

本植物同定には，花葉がなかったため，根茎の組織像 から試みざる得なかった，すなわら沼田地方に自生す る疑わしい植物種, フメリカヤ、ゴボウ, ムラサキケマ ン,フマドュロおよびョウシュチョウセンアサガオの各 々の根茎組織像を比較検討したところ, 被験根茎は, 放 射性の中心柱を有し, 柔細胞内に砂粒状の萑酸石灰結晶 を含み，さらに特有な核とデンプン粒を多数もつ細胞が 証明される点から，ヨウシュチョウセンアサガオと同一 種に属する植物と同定された1)。

\section{4. 考 察}

本中原因については, 臨床症状, 動物実験, 植物 同定から，キンピラとして摄取された観賞用のヨウシュ チョウセンアサガオ根茥中に含有されていたbelladonna alkaloids (atropine および scopolamine) によること は明らかである. 河郎ら 2$)$ は, 昭和 46 年愛知県で発生し た同類の集団中毒事件について報告している.一般に本

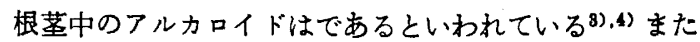
ヒトの atropine 中毒で幻覚などの精神症状を呈するに は $10 \mathrm{mg}$ 以上が摄取される必要があるとい5 事件ではキンピラを 1 人当り平均 $15 \sim 17 \mathrm{~g}$ 撕取してい ると推定され，また水性抽出液中の atropine よう物質 は $500 \mu \mathrm{g} / \mathrm{g}$ であったが, フルカロイド抽出が不完全で あったことを考虑すると根茥中のアルカロイド含有量は $1 \mathrm{mg} / \mathrm{g}$ に近いと想像される．将来同類の中毒事件に対 処するため，有毒植物根茎の標準組織学的所見をまとめ る必要が痛感された。

稿を終るに当り, 群馬大学医学部田所作太郎教授, 同 大教育学部山田義男教授, 沼田保健所下枝延子技師の御 指導，御協力をいただいたことに対し，厚く感謝いたし ます。

\section{文献}

1) 牧野：新日本植物図鑑，(1970) 北隆館, 東京.

2）河涱泳：食品衛生研究，21，747(1971).

3) 今関：薬誌. 76, 865(1956).

4）萩庭，原田：同上. 79, 1094 (1959).

5) Goodman, L. S., Gilman, A.: "The Pharmacological Basis of Jherapeutics" MacMillan Co., New York (1965).

(群馬県衛生研究所 原 善彦・樋口洋一郎 狩野和雄・滰島常雄・福島一郎) 


\section{食中 毒 事 件 既 刊目 次}

\section{昭和 29 年 (第 6 巻 1 号)}

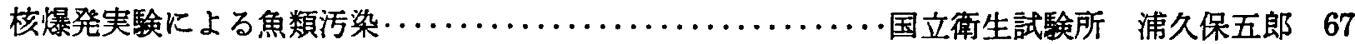

パラチオンによる食中毒死

·茨城県衛生研究所 佐谷戸安好 68

イカ, ワカメぬたによる工場給食食中毒………愛知県衛生部食品獣医務課 平松 茂 69

\section{昭和 30 年 (第 6 巻 1 号)}

脱脂粉乳による食中毒 東京都立衛生研究所 春田三佐夫 70 ゆでダコによる食中毒.$\cdots \ldots \ldots \ldots \ldots \ldots \ldots \ldots \ldots \ldots \ldots$ 東京都衛生局公衆衛生課 長 崎 護 71 新鮮イカによる食中毒 $\cdots \cdots \cdots \cdots \cdots \cdots \cdots \cdots \cdots \cdots \cdots$ 新潟県衛生部環境衛生課 名畑 武男 73 国立相模原病院のウイルス中毒…………神奈川県衛生部環境衛生課 松本 才治 75 調製粉乳によるヒ素中毒 $(6$ 巻 3 号 掲載) $\ldots \ldots \ldots \ldots \ldots \ldots \ldots$ 国立衛生試験所 川城 榐 318

\section{昭和 31 年 (第 6 巻 1 号)}

水俣病 国立衛生試験所 田辺 弘也 77 ボラによる食中毒 ·静岡県浜松保健所衛生課 宮松 総介 78 イシナギの肝蔵による食中毒 $\cdots \cdots \cdots \cdots \cdots \cdots \cdots \cdots \cdots \cdots$ 東京都立衛生研究所 春田三佐夫 80

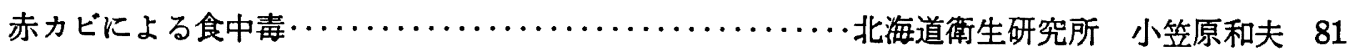

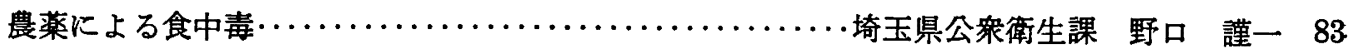
北海道亀田郡銭亀沢村に発生したボッリヌス中毒……...北海道衛生研究所 飯田 広夫 85

\section{昭和 32 年 (第 6 巻 1 号)}

揚パンによる食中毒 京都市衛生局環境衛生課 86 バイによる食中毒 新潟県衛生部環境衛生課 町田 正平 87

ミリン干による食中毒 ·宮城県衛生部環境衛生課 門間 洋 89

\section{昭和 33 年 (第 6 巻 2 号)}

イカの天ぷら (ヒ素) による食中毒 ·和歌山県衛生部公衆衛生課 青木 健二 197 にぎりめしによるブドウ球菌食中毒 .国立衛生試験所 鈴木 昭 198 桐油による食中毒 香川県公衆衛生課 多田 御幸 199 
横須賀市に発生した病原性大腸菌による食中毒について

·横須賀市中央保健所 内海長太郎・增田今朝康 201

オレンジジュースによるとみられる子供クラブの集団食中毒事件

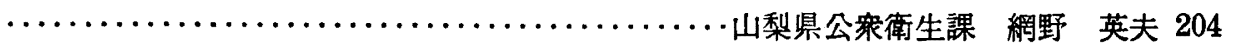

サルモネラによる食中毒

·滋賀県公衆衛生課 寺島 長剛 205

\section{昭和 34 年 (第 6 巻 2 号)}

ブドウ球菌によるアサリ食中毒事件.$\cdots \ldots \ldots \ldots \ldots \ldots \ldots \ldots$. 梨県公衆衛生課 網野 英夫 206 北海道富良野町に発生したウエルシー菌による食中毒.......北海道衛生研究所 飯田 広夫 208 病原性好塩菌による食中毒 ·神奈川県衛生研究所 宮 本 泰 209 ゆでダコによる食中毒……..................宮城県衛生部環境衛生課 門間 洋 210 五目豆腐中の豚肉学校給食による食中毒…….....静岡県清水保健所衛生課 楖原 義昌 212 病原大腸菌 0-146 による集団食中毒例について……...埼玉県衛生研究所 渡辺 昭宣 214

\section{昭和 35 年 (第 6 巻 2 号)}

イシナギの内臓による食中毒について……..........高知県窪川保健所 正岡 幸栄 216 イワシのミリン干中毒…………………京都衛生局公衆衛生課 長 崎 護 217 北海道夕張市に発生したウェルシュ一菌による食中毒……北海道衛生研究所 飯田 広夫 219 サルモネラトンプソンによる食中毒……長野県衛生部環境衛生課 米山 嶢・堀籠 静雄 220

\section{昭和 36 年 (第 6 巻 3 号)}

事業所給食集団サルモネラ中書 ·神奈川県衛生部 中町 俊雄 297 アカザラ貝による食中毒・ ·岩手県衛生研究所 中野 弥・飯岡邦夫 298 トビウオによる集団中毒 ·宮崎県衛生研究所 北尾 忠利 300 「サンマ飯ずし」による食中毒について…………秋田県厚生部公衆衛生課 三浦 栄一 301 タラよりのホルムアルデヒド検出………......東京都市場衛生検査所 持永 泰輔 303

\section{昭和 37 年 (第 6 巻 3 号)}

サラダ（サルモネラ）による学校給食食中毒 ·新潟県衛生部環境衛生課 金子 正弘 304 小学校に発生した集団下痢症. 川崎市衛生局衛生課 高橋善三郎 305 学校給食によるブドウ球菌食中毒 . 埼玉県衛生研究所 渡辺 昭宣 309 折詰による集団食中毒 -山口市保健所 守田 良之 311 


\section{昭和 38 年 (第 6 巻 3 号)}

シチューによる小学校給食食中毒 ...静岡県天竜市保健所 大関 孝一

静岡県浜松市北保健所 岩井 万作 312

野菜の塩もみによる共同炊事の食中毒………产省知県衛生部食品獣医務課 平松 茂 314 クジラベーコン事件 $\ldots \ldots \ldots \ldots \ldots \ldots \ldots \ldots \ldots \ldots \ldots$ 東京都衛生局公衆衛生課 長 畸 護 315 ウエルシー菌食中毒例.$\cdots \ldots \ldots \ldots \ldots \ldots \ldots \ldots \ldots \ldots \ldots \ldots$ 東京都立衛生研究所 辺野喜正夫 317

\section{昭和 39 年 (第 10 巻 2 号)}

ウェルシュ菌による食中毒 ·静岡県藤枝保健所 宮松 総介 101 もち取り粉（ヒ素）による食中毒 ·鹿児島県環境衛生課 田代 昌道 103

\section{昭和 40 年 (第 10 巻 2 号)}

S. typhimurium に污染された「あおのり」による集団中毒

埼玉県衛生研究所 渡辺 昭宣 104

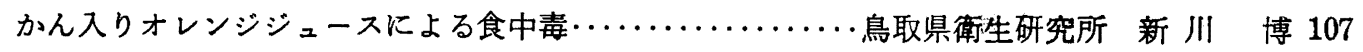

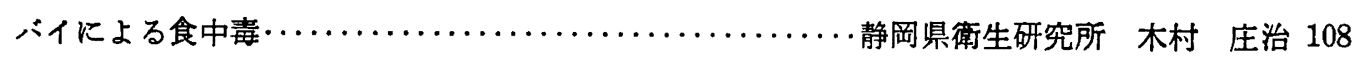

\section{昭和 41 年 (第 10 巻 2 号)}

ウェルシュ菌による食中毒…………………広島県衛生研究所 岸本 敬之 110

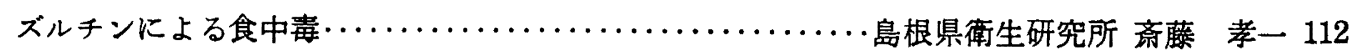
らどん中に混入したカドミウムおよび亜鉛による集団中毒について 